\title{
Colorectal Cancer in Elderly Patients with Surgical Indication: State of the Art, Current Management, Role of Frailty and Benefits of a Geriatric Liaison
}

\author{
Nicolás M. González-Senac ${ }^{1,+}{ }^{\mathbb{D}}$, Jennifer Mayordomo-Cava ${ }^{1,2,3,+}{ }^{\mathbb{D}}$, Angela Macías-Valle ${ }^{4}$, Paula Aldama-Marín ${ }^{1}$, \\ Sara Majuelos González 1,5, ${ }^{1}$, María Luisa Cruz Arnés ${ }^{1}$, Luis M. Jiménez-Gómez ${ }^{6} \mathbb{D}$, María T. Vidán-Astiz 1,2,3,7,* \\ and José Antonio Serra-Rexach 1,2,3,7
}

check for

updates

Citation: González-Senac, N.M.; Mayordomo-Cava, J.; Macías-Valle, A.; Aldama-Marín, P.; Majuelos González, S.; Cruz Arnés, M.L.; Jiménez-Gómez, L.M.; Vidán-Astiz, M.T.; Serra-Rexach, J.A. Colorectal Cancer in Elderly Patients with Surgical Indication: State of the Art, Current Management, Role of Frailty and Benefits of a Geriatric Liaison. Int. J. Environ. Res. Public Health 2021, 18, 6072. https://doi.org/10.3390/ ijerph18116072

Academic Editors: Francisco José Tarazona Santabalbina, Sebastià Josep Santaeugènia Gonzàlez, José Augusto García Navarro and José Viña

Received: 29 April 2021

Accepted: 29 May 2021

Published: 4 June 2021

Publisher's Note: MDPI stays neutral with regard to jurisdictional claims in published maps and institutional affiliations.

Copyright: (c) 2021 by the authors. Licensee MDPI, Basel, Switzerland. This article is an open access article distributed under the terms and conditions of the Creative Commons Attribution (CC BY) license (https:// creativecommons.org/licenses/by/ $4.0 /)$
1 Geriatric Department, Hospital General Universitario Gregorio Marañón, 28007 Madrid, Spain; nic.gsenac@gmail.com (N.M.G.-S.); jennifer.mayordomo@gmail.com (J.M.-C.); paula.aldama.marin@gmail.com (P.A.-M.); saramajuelos@gmail.com (S.M.G.); mcarnes@salud.madrid.org (M.L.C.A.); joseantonio.serra@salud.madrid.org (J.A.S.-R.)

2 Instituto de Investigación Sanitaria Gregorio Marañón, 28007 Madrid, Spain

3 Biomedical Research Networking Center on Frailty and Healthy Aging, CIBERFES, 28029 Madrid, Spain

4 School of Physical Activity and Sport Sciences, Universidad Politécnica de Madrid, 28040 Madrid, Spain; angela.macias.valle@alumnos.upm.es

5 Centro Asistencial San Camilo de Tres Cantos, 28760 Madrid, Spain

6 General Surgery Department, Hospital General Universitario Gregorio Marañón, 28007 Madrid, Spain; luismiguel.jimenez@salud.madrid.org

7 School of Medicine, Universidad Complutense, 28040 Madrid, Spain

* Correspondence: maite.vidan@salud.madrid.org

$+\quad$ These authors contributed equally to this work.

$\ddagger$ Majuelos González is in collaboration with Fundación La Caixa.

\begin{abstract}
Six out of every 10 new colorectal cancer (CRC) diagnoses are in people over 65 years of age. Current standardized surgical approaches have proved to be tolerable on the elderly population, although post-operative complications are more frequent than in the younger CRC population. Frailty is common in elderly CRC patients with surgical indication, and it appears to be also associated with an increase of post-operative complications. Fast-track pathways have been developed to assure and adequate post-operative recovery, but comprehensive geriatric assessments (CGA) are still rare among the preoperative evaluation of elderly CRC patients. This review provides a thorough study of the effects that a CGA assessment and a geriatric intervention have in the prognosis of CRC elderly patients with surgical indication.
\end{abstract}

Keywords: colorectal cancer; elderly; frailty; geriatric syndromes; comprehensive geriatric assessment; geriatric liaison; multicomponent programs; functional capacity

\section{Highlights}

(1) Individualizing interventions in the colorectal cancer elderly population undergoing elective surgery could boost the benefits of fast-track pathways (as ERAS program), which may be gained by CGA-guided care and a geriatric liaison or co-management.

(2) CGA should be the first step towards a multidisciplinary network which would give the patient access to a personalized pre-habilitation and rehabilitation program.

\section{Background}

\subsection{Epidemiology}

Colorectal cancer (CRC) is the third most common cancer in the world. In 2019, the worldwide number of new CRC cases was 1,931,590, which accounts for $10 \%$ of new cancer diagnosis. The median age of CRC diagnosis is 67 years, with $56 \%$ of the cases newly diagnosed corresponding to patients $\geq 65$ years, and $31 \%$ to patients $\geq 75$ years [1]. The 
median age at death is 72 years, and $45 \%$ of the deaths occur in patients $\geq 75$ years old, with $21 \%$ of them in the oldest ( $\geq 85$ years) [1]. The incidence of CRC has increased in countries with a medium-high human development index (HDI), whilst it has stabilized—or even declined-in some of the highest HDI, such as the United States [2] or certain European countries, possibly linked to the effect of screening CRC programs [3], changes in lifestyle and dietary habits $[4,5]$. Although more than $90 \%$ of colorectal carcinomas are adenocarcinomas, other rare types include neuroendocrine, squamous cell, adenosquamous, spindle cell and undifferentiated carcinomas [6].

\subsection{Risk Factors}

Main risk factors for the development of CRC are positive family history [7], male sex and advanced age, although lifestyle-related factors such as smoking, processed/red meat and alcohol intake, low-fruit and vegetable diets and increased bodyweight are also of importance [5,8].

\subsection{Screening for Colorectal Cancer}

The lack of specificity in CRC symptoms makes screening highly relevant, and many tests have been developed over the years (e.g., stool test, colonoscopy). It is generally recommended to give patients the opportunity to choose the test of their preference, as that may increase adherence to the screening program [9]. It appears that the early detection by screening may have contributed to the reduction of mortality by decreasing incidence (removing precancerous polyps) and increasing survival (detecting the disease at an early stage) $[8,10]$. Since the early 2000 s a decrease in the elective and emergency admission rates for CRC resection ( $8 \%$ and $6 \%$, respectively) has been observed in the U.S. aging population ( $\geq 65$ years) [11].

Screening is carried out mainly in patients between 60 and 70 years of age [12], although it is recommended for subjects of 50 years and older [13]. A large proportion of patients 80 years and older still require urgent admissions, which could be related to the possible lack of screening in elderly patients. Moreno et al. described how only $4 \%$ of CRC diagnosis in elderly patients ( $>75$ years) of a medical institution in the U.S. were determined through screening colonoscopy, whereas in younger patients (range: 50-75 years) this percentage rose to $14 \%$ [14]. Both the U.S. Preventive Services Task Force and the American Cancer Society recommend CRC screening until the age of 75 years (when life expectancy is greater than 10 years) and individualization in patients between 76 to 85 years, as in this age group screening benefits decrease while the risk of suffering associated complications increases $[9,15]$. The U.S. Multi-Society Task Force of Colorectal Cancer suggests continuing screening up to 85 years only if no previous screening has been done, and stopping it at 75 years if prior screening tests have been negative [16]. Interestingly, Van Hees et al. carried out a microsimulation modeling study to try to determine at what age CRC screening should still be considered and they concluded that in unscreened elderly without comorbidity colonoscopy screening was cost-effective up to age 85 years, decreasing to 82 and 79 years in the case of elderly patients with moderate to severe comorbidities, respectively [17].

\subsection{Colorectal Cancer Management}

Endoscopic management is achievable in early malignant lesions, but surgery remains the main foundation of CRC treatment. According to the U.S. Healthcare Cost and Utilization Project Nationwide Inpatient Sample, comprised by 1,043,108 patients over 45 years of age that had undergone CRC resection, most of them (64\%) were 65 years or older, including 29\% septuagenarians and 23\% octogenarians and nonagenarians [11]. Even though a mean decrease in mortality after CRC surgery was described in the early 2000s (being this improvement most notable in patients 85 years and older) [11], and that longterm survival is achieved in the surgical CRC elderly population [10], it has been stated in the literature that differences of CRC management exist between age groups. Elderly 
patients are less likely to undergo CRC surgery in comparison to younger individuals [18]. Simmonds et al. showed how, in a population of 34,194 patients with CRC from various studies, $21 \%$ of those aged over 85 years did not undergo operation, while the rates of no surgical intervention were $11 \%$ in the $75-84$ years age group, $6 \%$ in the $65-74$ group and $4 \%$ in those aged 64 years or younger. Additionally, $33 \%$ of the surgeries performed in patients over 85 years had a palliative intent [19].

Also, elderly patients with a more advanced tumor stage were less often offered adjuvant therapy [18]. These differences have been sustained by other groups. Sell et al. recently described, in a retrospective analysis of patients with colon adenocarcinoma who underwent surgical resection in an American hospital, how younger patients (aged 79 years or less) were more likely to receive adjuvant chemotherapy when compared to octogenarians, with rates of $48 \%$ vs. $9 \%$, respectively. Although they found phenotypic tumor differences between groups (octogenarians presented with larger tumors but less extra-colonic spread) the difference in adjuvant therapy remained when analyzing patients of all stages and when excluding those with American Joint Committee on Cancer Stage IV disease. Interestingly, they also described how in younger patients the use of chemotherapy increased with tumor size, while in the elderly it decreased [20]. Serra-Rexach et al. conducted a retrospective cohort study in a Spanish university hospital in which it was found that age was the main reason for different therapeutic approaches in elderly ( $\geq 75$ years) and younger ( $<75$ years) CRC patients. Although no differences were observed between groups in tumor degree of differentiation, extension or stage at diagnosis, those individuals aged over 75 years were less likely to receive surgery, radiotherapy, and chemotherapy [21]. Older population is frequently underrepresented in randomized clinical trials (RCTs) [22] and, consequently, it is difficult to reach evidence-based clinical recommendations that apply to the treatment of the elderly CRC population [23].

Laparoscopic surgery (LS) has gained importance over the years due to its short-term beneficial results compared to open colectomy (e.g., decreased post-operative morbidity, faster recovery of bowel function, reduction on length hospital of stay (LOS)) with a low rate of conversion to open surgery (OS) [24-26]. It has proven to be an effective and safe procedure for treating elderly CRC patients [27]. A matched case-control study by Hinoi et al. which only included elderly patients with a diagnosis of colon or rectum adenocarcinoma (median age: 83 years) pointed out how the outcomes of LS in this population are not inferior to those of OS [28]. Regarding the surgical act, they showed how the LS approach-for both colon and rectal cancer-was longer in duration, but had lower blood loss. In the post-operative period, patients who had undergone LS for colon cancer had a faster return of bowel function, a shorter hospital stay and were able to initiate fluid and solid diet in less time than OS patients. Those who had undergone rectum LS also had a faster return of bowel function and initiated fluid diet in less time than OS patients, but no differences were found regarding time to solid intake and hospital stay. Post-operative morbidity rates in colon cancer cases were $36 \%$ in the OS group and $25 \%$ in the LS group, at the expense of a reduction in the occurrence of delirium, organ/space surgical site infection and pneumonia. Although the post-operative morbidity rates in rectum patients were also lower ( $40 \%$ vs. $47 \%$ ), the difference was not statistically significant [28]. Kannan et al. also observed how post-operative complications on elderly patients who had undergone laparoscopic partial colectomy were significantly fewer than in those that had undergone open partial colectomy, including every subcategory (cardiac, pulmonary, renal, and infectious). Additionally, the LS group had lower rates of unplanned return to the operating room, their LOS was shorter and 30-day mortality was also significantly lower [29].

Adjuvant therapy can be considered in high-risk Stage II patients (e.g., poorly differentiated tumor, vascular or perineural invasion, lymph nodes sampling $<12$, tumor presentation with obstruction or perforation) and is recommended in Stage III patients, as it improves survival $[5,10]$. As rectal cancer surgery is more complex, its approach tends to be different, and neoadjuvant radiotherapy is common [5]. 


\section{Characteristics of Elderly Colorectal Cancer Population That Undergo Surgery}

\subsection{General Colorectal Cancer Characteristics}

\subsubsection{Disease Presentation}

Patients over 75 years old are more likely to present with later-stage disease and to undergo emergency surgery [19]. Bircan et al. retrospectively analyzed the characteristics of 265 patients that had undergone a programmed colorectal surgery at two Turkish institutions and found that the most common causes of admission differed between age groups: blood stool for patients aged 60-69 years, bowel obstruction for those aged between $70-79$ years and anemia for the oldest ( $>80$ years) [30]. Although these last findings could be due to the inclusion of non-malignant colon surgeries in the study, differences like these can also be attributed as stated by the Colorectal Cancer Collaborative Group [19] to age-related variances in recognizing symptoms or seeking medical advice, as well as to primary-care referral patterns.

\subsubsection{Complications and Post-Surgical Survival}

Although intraoperative complications do not seem to be more frequent among elderly CRC patients [30-32], no clear consensus exists regarding surgical post-operative complications. Some authors have described that elderly patients suffer more ileus, peritonitis/septic shock, pelvic abscess, incisional/post-herniation and have significant longer time to first flatus, bowel motion or to resume normal diet compared to younger patients [31]. Others have not reported differences regarding post-operative surgical complications between age groups [30]. These last findings were also found in a prospective multicenter study conducted by the Colon/Rectum Cancer Working Group that included 19,080 surgical CRC patients: the rate of surgical post-operative complications was not higher in the elderly group ( $\geq 80$ years) compared to the younger one [32].

Regarding systemic post-operative complications, all studies agree on how they tend to be more frequent in the elderly when compared to younger CRC patients. This type of complications includes respiratory [11,31,32], cardiovascular [11,31,32], renal [31,32], and infectious [11,31,32], among others. There is also certain consensus on how elderly CRC patients have longer LOS which may be attributed to, precisely, the higher rates of post-operative complications [11,30-33]. Kunitake et al. described an increase of 90-day post-discharge readmission rates in the elderly of a large CRC population $(83,897$ with colon cancer, 26,794 with rectal cancer). These readmissions were mainly justified by non-surgical complications and associated with higher comorbidity and male gender [33].

Although mortality after CRC surgery in the elderly has decreased in the past few years [11], age is an independent predictor of post-operative mortality following CRC resection [34,35]. Excess mortality is sustained throughout the whole year after CRC surgery, and most patients seem to die after the 30-day post-operative period, especially those aged 75 years or more [36]. Interestingly, older CRC patients who survive the first year after surgery may have the same overall cancer-related survival as younger patients [37].

\subsection{Geriatric Syndromes}

Geriatric syndromes (GS), such as cognitive impairment, functional dependency, falls or urinary incontinence, are clinical conditions more commonly detected on elderly patients. Its cause is believed to be multifactorial, and their presentation is the result of the accumulation of impairments in different systems and the inability of the individual to compensate for them. In the elderly population, GS are associated with higher risk of hospitalization and mortality. Both cancer and oncologic treatments can behave as potential stressors that may overwhelm the patient's reserve capacity and, consequently, favor the development of GS. Therefore, the assessment of GS in the elderly cancer population is of interest when designing care plans or interventions [38]. 


\subsubsection{Functional Dependency}

Functional dependency, understood as a person's inability to live independently and perform basic activities of daily living, has proved to be a predictor of morbidity and mortality in the elderly population [39]. It has also been independently associated with shorter survival time in cancer patients [40].

In a systematic review by Hamaker et al. that gathered 23 studies which assessed long-term physical and role functioning changes in CRC patients after treatment, it was discovered that both physical and role functioning were significantly limited at three months after treatment [41]. Ronning et al. in an observational prospective cohort that evaluated predictors of postoperative complications in older patients with CRC, found a significant decline in both basic activities of daily living (ADLs) and instrumental activities of daily living (IADLs) in the 16-28 months that followed surgery, measuring ADLs and IADLs with Barthel Index and the Nottingham Extended Activities of Daily Living Scale, respectively [42].

\subsubsection{Frailty}

Frailty is a dynamic clinical state characterized by an increased vulnerability to stressors that leads to a loss of homeostasis and a subsequent increase in the risk of developing adverse outcomes (such as disability, falls, delirium or death) [43,44]. Traditionally, it has been defined by two different models: the phenotype model [45] and the deficit accumulation model [46], both of which have showed overlap in their identification of frailty and statistical convergence [43]. The prevalence of frailty among community-dwelling older adults is variable, between $11 \%$ in subjects over 65 years of age (ascending to $16 \%$ in those aged $80-84$ years and $26 \%$ in those aged $\geq 85$ years) [47]. Regarding cancer patients, in a sample of 2349 Medicare beneficiaries with 65 years or more and a history of cancer the prevalence of frailty ranged from $46 \%$ to $80 \%$ [48]. It has been described in the literature how cancer patients and those who are undergoing surgery are more likely to be frail and have more adverse outcomes than those who are not frail [49]. As a result of this, oncologic scientific societies like the International Society of Geriatric Oncology (SIOG) recommend the screening of frailty in older cancer patients [50]. However, there is no standard evaluation and several tools to identify frail cancer patients have been developed, such as the Balducci criteria [51], the Vulnerable Elders Survey-13 [52] and the G8 Geriatric Screening Tool [53], among others. Many of these tools consider comorbidities, cognition, nutritional status, functionality, and physical performance as components of frailty, and others like the Fried criteria [45] only focus on a physical phenotype. Consequently, the prevalence of frailty in older individuals with CRC and surgical indication ranges between $25 \%$ and $46 \%$, a variability that depends on both the population studied and the tools used to measure it [54]. It has been proposed that, regarding CRC treatment in the elderly, standard approaches may be offered to robust CRC patients while a need for an individualized therapeutic plan must be considered on frail CRC patients [55].

Using frailty as a risk-stratification tool in surgical elderly patients is a relatively new concept that could change their pre-operative assessment paradigm, as a growing body of scientific evidence has emerged over the past few years. Robinson et al., in a prospective cohort study that included patients $\geq 65$ years undergoing elective colorectal or cardiac surgeries, described how those classified as frail had a higher risk of developing post-operative complications. The definition of frailty they used was based in a deficit accumulation model in which frailty was detected when at least 4 of 7 frailty-related characteristics (regarding function, cognition, chronic disease burden, walking speed, nutrition and geriatric syndromes) were met [56]. Independently of the way frailty is assessed, studies in CRC are concordant in the association of frailty and an increased risk of postoperative complications and mortality. Table 1 shows a detailed description of the main studies that have assessed the influence of frailty (defined by different criteria, such as the Groningen Frailty Indicator (GFI), the Fried Criteria and a modified version of the Balducci criteria) on post-operative outcomes in CRC patients, with similar results. 


\subsubsection{Cognitive Impairment and Mental Health}

The prevalence of dementia in patients with CRC is not clear. Gupta et al. in a population-level cohort study that included 17,507 patients of 67 years or more of the SEER-Medicare file diagnosed with colon cancer, found that the prevalence of dementia in newly-diagnosed patients was 7\%. Also, they described how dementia patients were not only twice as likely to be diagnosed with non-invasive methods (without biopsy) but also twice as likely to have their cancer diagnosed after death [57].

The most frequently described psychological alterations in oncologic patients are reactive conditions, mainly adjustment disorder, followed by depressed mood and anxiety [58]. It has been described how depression prevalence in cancer patients can range from $0 \%$ to $58 \%$, with this variability attributed to factors such as tumor type, stage of the disease, assessment instruments or diagnostic criteria employed [59]. Few data regarding mental illness in CRC patients have been published, but both depression and anxiety are common in this population, with published prevalence rates that range between $2-57 \%$ and $1-47 \%$, respectively [60]. In a recent cohort study, Lloyd et al. described an increase in any mental illness (including depression, anxiety, and adjustment disorders, among others) in CRC survivors since diagnosis. They also found that risk factors for mental illness among CRC survivors include colostomy, female gender (for depression), radiation therapy, chemotherapy, older age, advanced disease, and comorbid conditions. CRC survivors who developed mental illness had increased mortality [61]. Regarding age, some studies have observed higher rates of depression in elderly CRC patients, but no difference on anxiety levels $[62,63]$.

\subsubsection{Malnutrition and Social Support}

Malnutrition prevalence in cancer population ranges from 20-70\%, with differences attributed to patient's age, cancer type and stage $[64,65]$. In the elderly cancer subpopulation, malnutrition has been described as a risk factor for mortality, functional decline and, among others, poor treatment response [66]. In a prospective multi-center study whose primary objective was to evaluate the impact of a geriatric screening and assessment in elderly patients with cancer ( $n=1967$, median age 76 years, $22 \%$ with CRC) it was found that, according to the Mini Nutritional Assessment, $68 \%$ of the patients were at risk of malnutrition and $15 \%$ had malnutrition. It was also found how, following the assessment, the most frequently planned geriatric intervention was related to nutrition (57\%) [67].

Haviland et al. in a multicenter prospective cohort study that included 857 adult patients with CRC, found how-in a 2-year follow-up after surgery-levels of social support decreased over time and how health-related quality of life outcomes were associated with levels of social support. Also, their findings suggest that those patients with lower and declining social support were more likely to be older [68]. 
Table 1. Summary of studies in which the influence of frailty on post-operative outcomes in colorectal cancer populations was assessed.

\begin{tabular}{|c|c|c|c|c|c|c|}
\hline Author, yr. & Sample (n) & Age (yr.) & Setting & Frailty Measure & Frailty Prevalence & Outcomes \& Results \\
\hline Kristjansson el al. (2010) [69] & 178 & $\begin{array}{l}\text { Mean: } 80 \\
\text { SD: } 6 \\
\text { Range: 70-94 }\end{array}$ & $\begin{array}{l}\text { Hospitalization } \\
\text { Elective surgery }\end{array}$ & $\begin{array}{l}\text { CGA (Frail: } \geq 1 \text { domain affected) } \\
\text { - Barthel }<19 \\
\text { - NEADL: NR } \\
\text { - CIRS: any grade } 4 />2 \text { comorbidity grade } 3 \\
\text { - MNA }<17 \\
\text { - MMSE }<24 \\
\text { - Polypharmacy }>7 \\
\text { - GDS }>13\end{array}$ & $\begin{array}{l}\text { F: } 76(43 \%) \\
\text { NF: } 102(57 \%)\end{array}$ & $\begin{array}{l}\text { 30-Day Postoperative Complications } \\
\text { Any complication (Clav. I-IV) } \\
\text { RR 1.59, 95\% CI (1.25-2.01) } \\
\text { F: } 58(76 \%) \text {, NF: } 59(48 \%) \\
\text { Severe Complications (Clav. } \geq \text { II) } \\
\text { RR } 1.75,95 \% \text { CI }(1.28,2.41) \\
\text { F: } 47(62 \%), \text { NF: } 36(35 \%)\end{array}$ \\
\hline Reisinger et al. (2015) [71] & $153 *$ & $>70$ & $\begin{array}{l}\text { Hospitalization } \\
\text { Elective surgery }\end{array}$ & $\begin{array}{l}\text { GFI (Frail: } \geq 5 / 15 \text { ) } \\
\text { - Mobility } \\
\text { - Cognition } \\
\text { - Nutrition } \\
\text { - Vision } \\
\text { - Hearing } \\
\text { - Co-morbidity } \\
\text { - Physical fitness } \\
\text { - Psychosocial }\end{array}$ & $\begin{array}{l}\text { F: } 39(26 \%) \\
\text { NF: } 114(75 \%)\end{array}$ & $\begin{array}{l}\text { Postoperative Sepsis } \\
\text { OR 3.96, 95\% CI }(1.14-13.83) \\
\text { F: } 6(15.4 \%), \text { NF: } 5(4.4 \%) \\
p=0.03\end{array}$ \\
\hline Tan et al. (2012) [72] & 83 & $\begin{array}{l}\text { Mean: } 81 \\
\text { Range: 75-93 }\end{array}$ & $\begin{array}{l}\text { Hospitalization } \\
\text { Elective surgery }\end{array}$ & $\begin{array}{l}\text { Fried Criteria (Frail: } \geq 3 / 5) \\
\text { - Weigth loss }(\geq 10 \mathrm{lb},>5 \%) \\
\text { - Physical exhaustion } \\
\text { - Physical activity level } \\
\text { - Grip strenght } \\
\text { - Walking speed }\end{array}$ & $\begin{array}{l}\text { F: } 23(28 \%) \\
\text { NF: } 60(72 \%)\end{array}$ & $\begin{array}{l}\text { Major Postoperative Complications } \\
\text { (Clav. } \geq \text { II) } \\
\text { OR 4.083, 95\% CI (1.433-11.638) } \\
\text { F: } 11(47.8 \%), \text { NF: } 11(18.3 \%) \\
p=0.006\end{array}$ \\
\hline
\end{tabular}

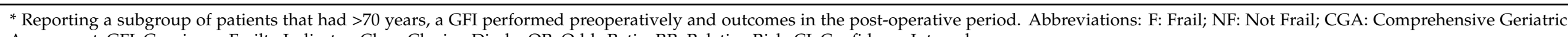
Assessment; GFI: Groningen Frailty Indicator; Clav.: Clavien-Dindo; OR: Odds Ratio; RR: Relative Risk; CI: Confidence Interval. 


\section{Multidisciplinary Team and Comprehensive Interventions in Colorectal Cancer Patients}

To assure an adequate recovery after major abdominal surgery, fast-track pathways such as the Enhanced Recovery After Surgery (ERAS) program have been developed. Among other elements, ERAS programs include preoperative counselling, preferred laparoscopic approach, avoidance of nasogastric tubes or drains when not necessary, enforcement of postoperative early mobilization or feeding and detailed postoperative nursing-care programs $[73,74]$. It has been described how the implementation of at least four ERAS elements in the colorectal surgery pathway reduces LOS and the rate of post-operative complications without increasing readmission or mortality risk [75]. Its feasibility and benefits in elderly patients who undergo CRC surgery have already been described as well [76]. However, fast-track surgery programs do not discriminate between frail or robust elderly patients, which is of importance considering the higher rates of complications in the former collective.

\subsection{Benefits of a Geriatrics Liaison}

The Comprehensive Geriatric Assessment (CGA) has been defined as a "multidimensional interdisciplinary diagnostic process intended to determine a frail elderly's person's medical, psychosocial and functional capabilities and limitations in order to develop an overall plan for treatment and long-term follow-up" [77]. It encompasses many domains of an elderly's life to ensure the detection of a wide variety of problems (such as cognitive disorders, depression, social isolation, frailty, comorbidities, undernutrition, polypharmacy, and other geriatric syndromes) so that they can be properly managed to ensure the patient's well-being and independence.

To address the heterogeneity of elderly patients with cancer and guide oncologic treatment decisions, scientific societies such as the SIOG have recommended improving scientific research regarding CGA and cancer patients [78]. Although it has been described how CGA can contribute to the detection of problems and risks often unrecognized in regular oncologic assessments, or how CGA components have predictive risk of complications and toxicity related to treatment, a lack of standardized assessment tools and the heterogeneity regarding CGA models in geriatric oncology difficult its implementation [78]. Nevertheless, in the most recent American Society of Clinical Oncology Guideline for Geriatric Oncology, a CGA is recommended to all patients 65 years of age or older that are receiving chemotherapy [48], and many randomized controlled trials have shown that CGA-guided interventions improve key outcomes for older patients with cancer [79]. Unfortunately, its use in daily practice is complex and time-consuming.

There are studies which show how a geriatric co-management (including both preoperative and postoperative care) in older patients undergoing cancer-related surgery is associated with a reduction of LOS [80] and a lower 90-day postoperative mortality [81]. As a result of this, individualizing interventions in the CRC elderly population undergoing elective surgery could boost the benefits of ERAS programs, which may be gained by CGA-guided care and a geriatric liaison or co-management. Interestingly, few surgeons appear to collaborate on a regular basis with geriatricians [82].

CGA-guided assessments in CRC patients can function as a risk assessment or as a tool to design individualized patient-centered interventions. Many studies have been described with conflicting results. Lee et al. carried out a retrospective review of a prospective single-center database to assess whether a preoperative CGA in 240 elderly patients (aged 70 years or more) who had undergone elective CRC surgery was effective in predicting postoperative morbidity. This CGA included several domains (comorbidity, polypharmacy, physical function, cognitive, depression and nutrition), and a "high-risk" patient was defined as one who had deficits in at least two of those domains. A total of 95 high-risk patients (40\%) were detected, and this condition was significantly and independently associated with postoperative complications. As well, they found how 
greater independence in ADLs and fewer comorbidities were predictive of a less eventfuland therefore better-recovery [83].

Shipway et al. evaluated the efficacy of an embedded geriatric liaison service for emergency and elective gastrointestinal surgery using a retrospective control and a preoperative, in-hospital and post-operative CGA and intervention. The primary aim of the study was the reduction in LOS. They included 682 patients (203 pre-intervention, 479 post-intervention). A total of 132 patients in the intervention group were referred to the preoperative CGA-based assessment (from which $60 \%$ had CRC) and $26 \%$ of them were considered unfit and did not proceed with surgery. Two hundred and thirty-three inpatient reviews were conducted, being some of the most frequent indications discharge planning, communication with family, high dependency unit interventions, fluid balance, cardiac assessment, and delirium. The implementation of this geriatric liaison service supposed a mean LOS reduction of 3 days considering all surgeries, and this reduction was maintained in patients aged 75 years or more. However, when considering patients admitted electively for cancer surgery, LOS reductions were not statistically significant, although a trend of greater reduction was observed with advancing age [84]. Ramirez et al. carried out a before-after study with the objective of assessing the effect that a geriatric co-management program had on the LOS of elderly patients admitted to a general surgery ward. The results of the study show how in both intervention subgroups (the emergency-admitted and the electively-admitted), LOS was lower when compared to the control, with the CRC group presenting a mean decrease of 9 days [85].

In-hospital geriatric co-management interventions have also been described. In a single-center retrospective cohort study that included 310 patients aged 70 years or older who were admitted for elective CRC surgery in a tertiary level hospital, it was found how a daily CGA-based hospital assistance was associated with a lower incidence of delirium and other geriatric syndromes (such as falls, pain, urinary incontinence, constipation, pressure ulcers, malnutrition, and immobility), as well as fewer blood transfusions. Nevertheless, they also found that the intervention group had higher rates of long hospitalizations, intensive care unit admissions, serious complications, and hospitalization within the year [86].

However, although these kinds of CGA interventions seem promising, there are studies that have not shown clear benefits. Indrakusuma et al. carried out a retrospective matched-controlled study with the main objective of assessing beneficial postoperative outcomes of a preoperative CGA in 443 elderly patients (aged 70 years or more) who underwent CRC surgery in two time periods. The most frequent preoperative interventions derived from the preoperative CGA assessment were detection of delirium risk (64\%), vitamin supplementation (64\%) and dietary supplementation (20\%). Contrary to benefits showed in the previously mentioned studies, in this study no differences regarding mortality, postoperative delirium or LOS were found when the intervention group was compared to the control group [87]. Similarly, an RCT of frail older patients that were to undergo CRC surgery, failed to detect benefits of a preoperative and tailored geriatric intervention focused on nutritional advice (34\%), increased medication $(30 \%)$, other healthcare professional referral $(30 \%)$ and exercise $(23 \%)$. No differences between groups were found regarding the rate of postoperative severe complications, reoperations, readmission, or mortality. However, they found that the intervention group experienced fewer medical non severe complications [70]. A detailed description of all these findings has been summarized in Table 2. 
Table 2. Summary of studies assessing the benefits of a geriatric liaison on the approach of colorectal cancer patients undergoing surgery.

\begin{tabular}{|c|c|c|c|c|c|c|}
\hline Author, yr. & $\begin{array}{c}\text { Sample } \\
\text { (n; Groups) }\end{array}$ & Age (yr.) ${ }^{\dagger}$ & Design & Type of Program \& Setting & Assessments \& Interventions & Benefits $\ddagger$ \\
\hline Shipway et al., 2018 [84] & $\begin{array}{c}682 \\
\text { CG: } 203 \\
\text { IG: } 479\end{array}$ & $\begin{array}{c}>60 \\
\text { CG: } 73(60-100) \\
\text { IG: } 73(60-94)\end{array}$ & $\begin{array}{l}\text { Single-center } \\
\text { before-after study }\end{array}$ & $\begin{array}{l}\text { Embedded Geriatric Liaison } \\
\text { Hospitalization } \\
\text { Elective \& Emergency GI } \\
\text { surgery }\end{array}$ & $\begin{array}{l}\text { Preoperative CGA } \\
\text { - Comorbidity } \\
\text { - Medication } \\
\text { - Nutrition Status } \\
\text { - Exercise Tolerance } \\
\text { - Cognitive Function } \\
\text { - Frailty } \\
\text { - Depression Assessment } \\
\text { - Functional Capacity } \\
\text { - Social Circumstances } \\
\text { - Screening Investigations } \\
\text { Postoperative Follow-Up } \\
\text { - Ward Rounds (selected patients) } \\
\text { - Discharge Plan } \\
\text { - Geriatrician-led rehabilitation ward } \\
\text { (selected patients) }\end{array}$ & $\begin{array}{l}\text { LOS (All Surgeries) } \\
\text { All Patients } \\
\text { Mean Reduction: } 3.1 \text { days } \\
95 \% \text { CI }(0.7-5.5), p=0.007 \\
\text { Patients } \geq 75 \text { years } \\
\text { Mean Reduction: } 3 \text { days } \\
\text { 95\% CI }(0.2-5.8), p=0.045 \\
\text { LOS (Elective Surgery) } \\
\text { All Patients } \\
\text { Mean Reduction: } 1.3 \text { days } \\
\text { 95\%CI }(-1.4-4.03) \\
\text { Patients } \geq 75 \text { years } \\
\text { Mean Reduction: } 5.2 \text { days } \\
\text { 95\% CI }(-1.7-12.1), p=0.099\end{array}$ \\
\hline $\begin{array}{c}\text { Tarazona- Santabalbina et al., } \\
2019[86]\end{array}$ & $\begin{array}{c}310 \\
\text { CG: } 107 \\
\text { IG: } 203\end{array}$ & $\begin{array}{c}\quad \geq 70 \\
\text { CG: } 75 \pm 5 \\
\text { IG: } 76 \pm 5\end{array}$ & $\begin{array}{l}\text { Single-center retrospective } \\
\text { cohort study }\end{array}$ & $\begin{array}{l}\text { In-Hospital Program } \\
\text { Elective CRC Surgery }\end{array}$ & $\begin{array}{l}\text { 8-Hour Ward Assessment/intervention } \\
\text { - Pressure Ulcers } \\
\text { - Pain } \\
\text { - Urinary Continence } \\
\text { - Constipation } \\
\text { - Delirium } \\
\text { Daily Ward Assessment } \\
\text { - Endovenous Catheters } \\
\text { - Medication } \\
\text { - Infections } \\
\text { - Thromboembolic Events } \\
\text { - Anemia } \\
\text { - Early Ambulation } \\
\text { - Fall Risk } \\
\text { - Hydration \& Nutrition } \\
\text { - Sleep Hygiene } \\
\text { - Sensory Impairment }\end{array}$ & $\begin{array}{l}\text { Delirium reduction } \\
\text { CG: } 31 \text { (29.2), IG: } 23 \text { (11.3) } \\
p<0.001 \\
\text { Geriatric Syndromes diagnosis * } \\
\text { CG: } 28 \text { (26.2), IG: } 21(10.3) \\
p<0.001 \\
\text { Blood transfusions reduction } \\
\text { CG: } 24 \text { (22.4); IG: } 18 \text { (8.9) } \\
p=0.001\end{array}$ \\
\hline
\end{tabular}


Table 2. Cont.

\begin{tabular}{|c|c|c|c|c|c|c|}
\hline Author, yr. & $\begin{array}{c}\text { Sample } \\
\text { (n; Groups) }\end{array}$ & Age (yr.) ${ }^{\dagger}$ & Design & Type of Program \& Setting & Assessments \& Interventions & Benefits $\ddagger$ \\
\hline $\begin{array}{c}\text { Ramirez-Martín et al., } 2020 \\
\text { [85] }\end{array}$ & $\begin{array}{c}175 \\
\text { CG: } 122 \\
\text { IG: } 53\end{array}$ & $\geq 80$ & $\begin{array}{l}\text { Single-center before-after } \\
\text { cohort study }\end{array}$ & $\begin{array}{l}\text { Emergency Surgery } \\
\text { Inpatients } \\
\text { - In-Hospital Collaborative } \\
\text { Management } \\
\text { Elective CRC Surgery } \\
\text { - Preoperative CGA \& } \\
\text { Intervention } \\
\text { - In-Hospital Collaborative } \\
\text { Management }\end{array}$ & $\begin{array}{l}\text { Preoperative CGA } \\
\text { - Not Specified } \\
\text { In-Hospital Management } \\
\text { - Daily Ward Monitoring } \\
\text { - Clinical Management Collaboration } \\
\text { - Discharge Planning }\end{array}$ & $\begin{array}{l}\text { LOS (days) } \\
\text { Emergency Admissions } \\
\text { CG: } 27.2 \text { (18.1), IG: } 16.6 \text { (10.7) } \\
p<0.01 \\
\text { Elective Surgery (CRC) } \\
\text { CG: } 19.1 \text { (13.4), IG: } 10.6 \text { (9.3) } \\
p<0.01\end{array}$ \\
\hline $\begin{array}{c}\text { Indrakusuma et al., } 2015 \\
\text { [87] }\end{array}$ & $\begin{array}{l}100^{* *} \\
\text { CG: } 50 \\
\text { IG: } 50\end{array}$ & $\begin{array}{c}\geq 70 \\
\text { CG: } 75 \text { (71-78) } \\
\text { IG: } 81(79-85)\end{array}$ & $\begin{array}{l}\text { Single-center retrospective } \\
\text { cohort and match-control } \\
\text { study }\end{array}$ & $\begin{array}{l}\text { Preoperative CGA \& } \\
\text { Intervention } \\
\text { Elective CRC surgery }\end{array}$ & $\begin{array}{l}\text { Preoperative CGA \& Intervention } \\
\text { - Full Medical Study } \\
\text { - Social Circumstances } \\
\text { - Review of Systems } \\
\text { - Functional Capacity } \\
\text { - Family History } \\
\text { - Full Physical Examination } \\
\text { - Laboratory Tests } \\
\text { - Cognitive Function } \\
\text { - Depression Assessment } \\
\text { - Nutritional Status }\end{array}$ & $\begin{array}{l}\text { Mortality } \\
\text { No significant differences } \\
\text { Postoperative Delirium } \\
\text { No significant differences } \\
\text { Postoperative Complications } \\
\text { No significant differences } \\
\text { Length of Stay } \\
\text { No significant differences }\end{array}$ \\
\hline Ommundsen et al., 2017 [70] & $\begin{array}{l}114 \\
\text { CG: } 62 \\
\text { IG: } 52\end{array}$ & $\begin{array}{c}>65 \\
\text { CG: } 79 \pm 8 \\
\text { IG: } 78 \pm 7\end{array}$ & $\begin{array}{l}\text { Multi-center randomized } \\
\text { controlled trial }\end{array}$ & $\begin{array}{l}\text { Preoperative CGA \& } \\
\text { Intervention } \\
\text { Elective CRC Surgery } \\
\text { - Frail Subjects }\end{array}$ & $\begin{array}{l}\text { Preoperative CGA } \\
\text { - Activities of Daily Living } \\
\text { - Use of Medication } \\
\text { - Comorbidity } \\
\text { - Nutritional Status } \\
\text { - Cognitive Function } \\
\text { - Depression Assessment }\end{array}$ & $\begin{array}{l}\text { Mild Postop. Complications } \\
\text { Mentioned. No specific data } \\
\text { provided } \\
\text { Postop. Complications (Clav. I-V) } \\
\text { No significant differences } \\
\text { Postop. Complications (Clav. II-V) } \\
\text { No significant differences } \\
\text { 30-Day Mortality } \\
\text { No significant differences } \\
\text { 3-Month Mortality } \\
\text { No significant differences } \\
\text { Length of Stay } \\
\text { No significant differences }\end{array}$ \\
\hline
\end{tabular}

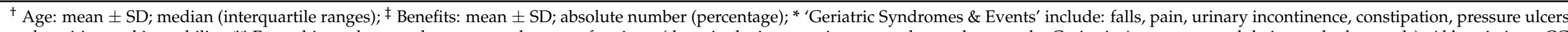

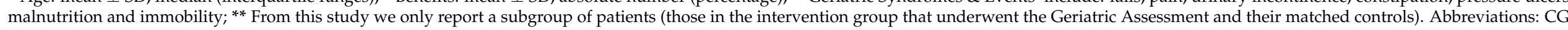
Control Group; IG: Intervention Group; GI: gastrointestinal; CGA: Comprehensive Geriatric Assessment; CRC: Colorectal Cancer; Postop: postoperative; Clav.: Clavien-Dindo. 


\subsection{Benefits of Exercise Programs}

Observational studies have shown how the highest level of physical activity (PA), before and after CRC diagnosis, is associated with a lower risk of CRC mortality [88-90]. Therefore, CRC patients should avoid physical inactivity whenever possible [91]. Although PA is beneficial in several aspects $[92,93]$ its benefits vary depending on factors such as the population included, the study design or the exercise programs themselves [94].

We found eleven RCTs assessing the effect of physical exercise in surgical CRC patients over the age of 60 years (mean age range: 60-81 years), with sample sizes from 42 to 185 patients (Table 3). The RCTs included multimodal programs with prehabilitation (before surgery) [95-98]. prehabilitation and rehabilitation (after surgery) [99-101] or comparing prehabilitation vs rehabilitation [102-105]. Prehabilitation's duration ranged between 2 and 4 weeks and rehabilitation from 4 to 8 weeks. Sessions were usually held one to three days per week for 30-60 min. Programs included exercise training alone [95,97,103], exercise training and psychological interventions with anxiety reduction strategies [98,99,102-105], adding in some of them a nutritional control $[95,98,99,101-105]$. Exercises included aerobic training [98], aerobic and resistance training [95,97,99-105], or only resistance training [96]. Aerobic training consisted of activities such as walking, treadmill walking or cycling, following the $150 \mathrm{~min} /$ week recommendations by the American College of Sport Medicine Guideline [88,91]. Resistance training consisted of exercises of the upper and lower limbs using elastic bands. Some of the RCTs did not report the exercise's intensity, but most of them opted for a moderate one [88,91] using the Borg Scale [97,99,102-104]. Home-based exercise sessions supervised weekly with phone calls were more prevalent $[96,98,99,102-105]$, although some programs were carried out at the hospital or exercise center $[97,100,101]$. As shown in Table 3, the results were variable. Some of the studies demonstrate an increase in functional capacity $[99,104,105]$, and others a decrease in postoperative complications $[95,101]$ or LOS $[100,101]$. Only two RCTs studied mortality, but no decrease was found in 30-day [100] or 1-year mortality [101] with the intervention. No differences regarding quality of life were found $[97,104]$. 
Table 3. Description of interventions and results of randomized controlled trials in older than 60 years with CRC.

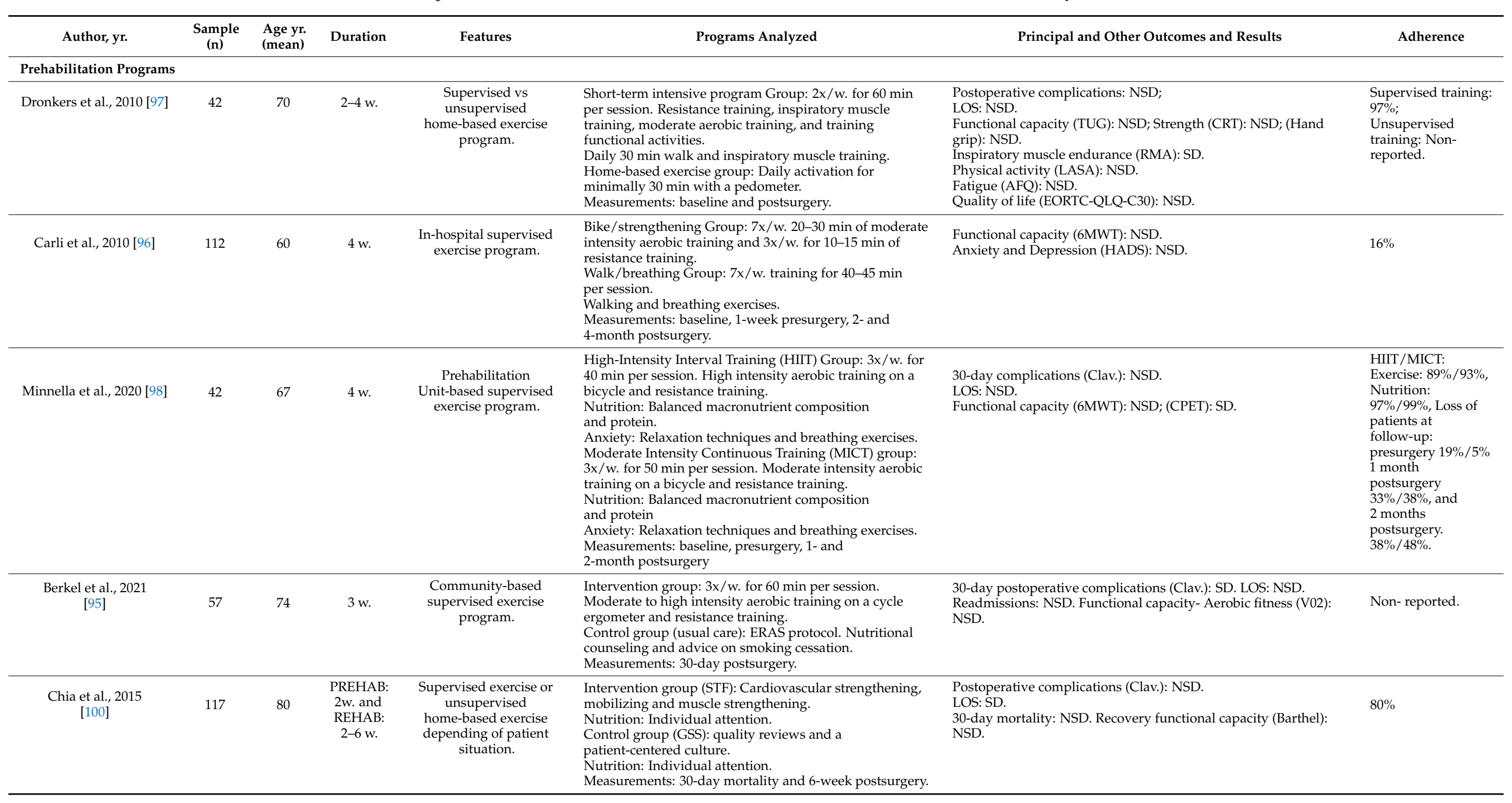


Table 3. Cont.

\begin{tabular}{|c|c|c|c|c|c|c|c|}
\hline Author, yr. & $\underset{\text { (n) }}{\text { Sample }}$ & $\begin{array}{l}\text { Age yr. } \\
\text { (mean) }\end{array}$ & Duration & Features & Programs Analyzed & Principal and Other Outcomes and Results & Adherence \\
\hline \multicolumn{8}{|c|}{ Prehabilitation Programs } \\
\hline $\begin{array}{c}\text { Awasthi et al., } 2018 \\
\text { [99] }\end{array}$ & 140 & 68 & $\begin{array}{l}\text { PREHAB: } \\
4 \mathrm{w} . \\
\text { and } \\
\text { REHAB: } \\
8 \mathrm{w} .\end{array}$ & $\begin{array}{l}\text { Supervised exercise and } \\
\text { unsupervised } \\
\text { home-based exercise } \\
\text { program. }\end{array}$ & $\begin{array}{l}\text { Group 1: unsupervised exercise (Gillis et al. 2014) 3x/w. } \\
\text { for } 50 \text { min per session: moderate intensity aerobic } \\
\text { exercise and moderate intensity resistance training. } \\
\text { Nutrition: Nutritional assessment and protein } \\
\text { supplementation. } \\
\text { Anxiety: Relaxation techniques. } \\
\text { Group 2: supervised training (Bousquet-Dion et al., 2018) } \\
\text { 1x/w. at hospital exercise laboratory for } 65 \text { min per } \\
\text { session: moderate aerobic exercise and resistance exercise. } \\
3 \text { to } 4 x / w \text {. at home for } 30 \text { min of moderate intensity } \\
\text { aerobic training and resistance training. } \\
\text { Nutrition: Nutritional assessment and protein } \\
\text { supplementation. } \\
\text { Anxiety: Relaxation techniques. } \\
\text { Measurements: baseline, before surgery, } 4 \text { - and } \\
\text { 8-week postsurgery. }\end{array}$ & $\begin{array}{l}\text { LOS: NSD } \\
\text { Functional capacity (6MWT): SD. } \\
\text { Muscle strength (Hand grip): SD. } \\
\text { Anxiety and depression (HADS): NSD. } \\
\text { Quality of life (SF36): SD. }\end{array}$ & $\begin{array}{l}\text { Supervised exercise } \\
98 \%\end{array}$ \\
\hline \multicolumn{8}{|c|}{ Prehabilitation Programs } \\
\hline $\begin{array}{c}\text { Souwer et al. } 2018 \\
\text { [101] }\end{array}$ & 86 & 81 & $\begin{array}{l}\text { PREHAB: } \\
4 \text { w. and } \\
\text { REHAB: } \\
4-6 \text { w. }\end{array}$ & $\begin{array}{l}\text { In-hospital supervised } \\
\text { exercise and home-based } \\
\text { exercise program. }\end{array}$ & $\begin{array}{l}\text { Intervention Group: } 2 \mathrm{x} / \mathrm{w} \text {. for } 30-45 \text { min per session. } \\
\text { PREHAB: Resistance and endurance training, and home } \\
\text { exercise and breathing. REHAB; Physical training. } \\
\text { Nutrition: Protein supplementation, dietary support. } \\
\text { Anxiety: Cognitive and emotional guidance. } \\
\text { Control group: usual care (previous cohort). } \\
\text { Measurements: } 30 \text {-day and 1-year postsurgery. }\end{array}$ & $\begin{array}{l}\text { 30-day postoperative complications. Only cardiac: SD. } \\
\text { LOS: SD. } \\
\text { 1-year mortality: NSD. }\end{array}$ & $63 \%$ \\
\hline $\begin{array}{l}\text { Gillis et al., } 2014 \\
\text { [104] }\end{array}$ & 77 & 66 & $\begin{array}{l}\text { PREHAB: } \\
4 \mathrm{w} . \\
\text { vS } \\
\text { REHAB: } \\
8 \mathrm{w} .\end{array}$ & $\begin{array}{l}\text { Unsupervised } \\
\text { home-based exercise } \\
\text { program. }\end{array}$ & $\begin{array}{l}\text { PREHAB: } 3 \times / w \text {. for } 50 \mathrm{~min} \text { per session. Moderate } \\
\text { intensity aerobic exercise and moderate } \\
\text { resistance training. } \\
\text { Nutrition: Protein intake. } \\
\text { Anxiety: } 60 \text { min of relaxation techniques and } \\
\text { breathing exercises. } \\
\text { REHAB Group: } 3 x / \mathrm{w} \text {. for } 50 \text { min per session. Moderate } \\
\text { intensity aerobic exercise and moderate } \\
\text { resistance training. } \\
\text { Nutrition: Protein intake. } \\
\text { Anxiety: } 60 \text { min of relaxation techniques and } \\
\text { breathing exercises. } \\
\text { Measurements: baseline, presurgery, } 4 \text { - and } \\
\text { 8-week postsurgery. }\end{array}$ & $\begin{array}{l}\text { 30-day complications (Clav.): NSD. } \\
\text { Functional capacity (6MWT): SD. } \\
\text { Health status (SF-36): NSD. } \\
\text { Anxiety and depression (HADS): NSD. }\end{array}$ & $\begin{array}{c}\text { PREHAB }=78 \% \text {; } \\
4 \text { w.: } 53 \% \text {; } \\
\text { 8w.: } 53 \% \\
\text { REHAB }= \\
4 \text { w.: } 31 \% \\
\text { 8w.: } 40 \%\end{array}$ \\
\hline
\end{tabular}


Table 3. Cont.

\begin{tabular}{|c|c|c|c|c|c|c|c|}
\hline Author, yr. & $\underset{(\mathrm{n})}{\text { Sample }}$ & $\begin{array}{l}\text { Age yr. } \\
\text { (mean) }\end{array}$ & Duration & Features & Programs Analyzed & Principal and Other Outcomes and Results & Adherence \\
\hline \multicolumn{8}{|l|}{ Prehabilitation Programs } \\
\hline $\begin{array}{c}\text { Minnella et al., } 2017 \\
\text { [105] }\end{array}$ & 185 & 68 & $\begin{array}{l}\text { PREHAB: } \\
4 \text { w. vs } \\
\text { REHAB: } \\
8 \mathrm{w} \text {. }\end{array}$ & $\begin{array}{l}\text { Unsupervised } \\
\text { home-based exercise and } \\
\text { supervised exercise } \\
\text { program. }\end{array}$ & $\begin{array}{l}\text { PREHAB Group: } 3 x / w \text {. for } 20-30 \text { min per session of endurance training } \\
\text { and } 2 x / \text { wo resistance training. } \\
\text { Nutrition: Dietary changes and protein supplementation. } \\
\text { Anxiety: Relaxation techniques. } \\
\text { Plus ERAS protocol. } \\
\text { REHAB Group: } 3 x / w \text {. for } 20-30 \text { min per session of endurance training } \\
\text { and } 2 x / \text { wo r resistance training. } \\
\text { Nutrition: Dietary changes and protein supplementation. } \\
\text { Anxiety: Relaxation techniques. } \\
\text { Plus ERAS protocol. } \\
\text { Measurements: baseline, presurgery, } 4 \text { - and } 8 \text {-week postsurgery. }\end{array}$ & $\begin{array}{l}\text { Postoperative complications (Clav.): NDS. } \\
\text { LOS: NSD. } \\
\text { Functional capacity (6MWT): SD. } \\
\text { Physical fitness (CHAMPS): SD. }\end{array}$ & $\begin{array}{l}\text { PREHAB }=70-98 \% \\
\text { REHAB } \% \\
4 \text { w.:53-72\% } \\
8 \text { w.: } 53-82 \%\end{array}$ \\
\hline \multicolumn{8}{|l|}{ Prehabilitation Programs } \\
\hline $\begin{array}{l}\text { Bousquet-Dion et al., } \\
2018 \\
{[102]}\end{array}$ & 80 & 73 & $\begin{array}{l}\text { PREHAB: } \\
4 \text { w. vs } \\
\text { REHAB: } \\
8 \text { w. }\end{array}$ & $\begin{array}{l}\text { In-hospital supervised } \\
\text { and unsupervised } \\
\text { home-based exercise } \\
\text { program. }\end{array}$ & $\begin{array}{l}\text { PREHAB Group: At hospital: } 1 \mathrm{x} / \mathrm{w} \text {. for } 65 \mathrm{~min} \text { per session. Moderate } \\
\text { aerobic exercise and resistance exercise. At home: } 3 \text { to } 4 \mathrm{x} / \mathrm{w} \text {. for } 30 \mathrm{~min} \\
\text { of moderate intensity aerobic training and resistance training. } \\
\text { Nutrition: Protein supplementation. } \\
\text { Anxiety: } 60 \text { min of relaxation techniques and breathing exercises. Plus } \\
\text { ERAS protocol. } \\
\text { REHAB Group: At hospital: } 1 \mathrm{x} / \mathrm{w} \text {. for } 65 \mathrm{~min} \text { per session. Moderate } \\
\text { aerobic exercise and resistance exercise. At home: } 3 \text { to } 4 \mathrm{x} / \mathrm{w} \text {. for } 30 \mathrm{~min} \\
\text { of moderate intensity aerobic training and resistance training. } \\
\text { Nutrition: Protein supplementation. } \\
\text { Anxiety: } 60 \text { min of relaxation techniques and breathing exercises. Plus } \\
\text { ERAS protocol. } \\
\text { Measurements: baseline, presurgery, } 4 \text { - and } 8 \text {-week postsurgery. }\end{array}$ & $\begin{array}{l}\text { LOS: NSD. } \\
\text { Functional capacity (6MWT): NSD. } \\
\text { Physical activity (CHAMPS): NSD. }\end{array}$ & $\begin{array}{l}\text { Supervised exercise, } \\
\text { PREHAB } 98 \% \\
\text { REHAB }=4 \text { w. } 70 \% \\
8 \text { w.: } 75 \%\end{array}$ \\
\hline Carli et al., 2020 [103] & 110 & 78 & $\begin{array}{l}\text { PREHAB: } \\
4 \mathrm{w} . \\
\text { vs } \\
\text { REHAB: } \\
4 \mathrm{w}\end{array}$ & $\begin{array}{c}\text { Unsupervised } \\
\text { home-based multimodal } \\
\text { program with } 1 \text { session } \\
\text { /w. supervised at } \\
\text { hospital (similar for } \\
\text { PREHAB and REHAB). }\end{array}$ & $\begin{array}{l}\text { PREHAB group: } 1 \mathrm{x} / \mathrm{w} \text {. for } 60 \text { min per session. } \\
\text { Supervised moderate aerobic exercises and resistance exercises at } \\
\text { hospital and moderate intensity aerobic activities (walking) and } \\
\text { resistance training at home. } \\
\text { Nutrition: Protein intake. } \\
\text { Anxiety: Relaxation techniques and breathing exercises. } \\
\text { REHAB group: } 3 x / \text { w. for } 30 \text { min per session. } \\
\text { Supervised moderate aerobic exercises and resistance exercises at } \\
\text { hospital and moderate-intensity aerobic activities (walking) and } \\
\text { resistance training at home. } \\
\text { Nutrition: Protein intake. } \\
\text { Anxiety: Relaxation techniques and breathing exercises. } \\
\text { Measurements: } 4 \text {-week postsurgery. }\end{array}$ & $\begin{array}{l}\text { 30-day postoperative complications (CCI and Clav.): } \\
\text { NSD. } \\
\text { LOS: NSD. } \\
\text { Functional capacity (6MWT): NSD. } \\
\text { Readmissions: NSD. }\end{array}$ & $\begin{array}{c}\text { PREHAB }=68 \% \\
\text { REHAB }=14 \% \text {. } \\
\text { General exercise } \\
\text { and nutrition: } \\
\text { PREHAB } 80 \% \text {, } \\
\text { REHAB } 30 \% .\end{array}$ \\
\hline
\end{tabular}

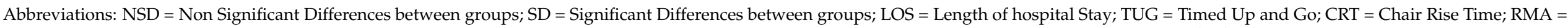

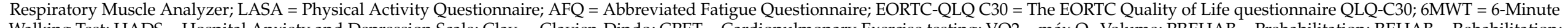

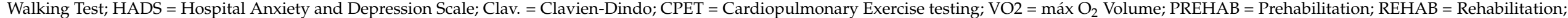

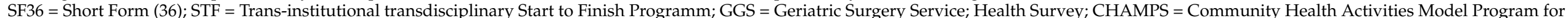
Seniors; ERAS = Enhanced Recovery After Surgery; CCI = Comprehensive Complications Index; yr. = years; $w$. = weeks; min = minutes. 
It is difficult to determine which is the most appropriate type of exercise program for elderly CRC population due to its heterogeneity [106]. The design of these programs must be adapted to the characteristics of the population studied (regarding functional capacity, frailty, comorbidity, etc.), the proposed outcomes (e.g., functional capacity recovery, change in functional state, reduction on complications or mortality, shortened LOS), the type of program (timing, duration, intensity ... ) and patient's preferences.

\subsection{Benefits of Psychotherapeutic Interventions}

Psychotherapeutic interventions have been described in CRC population, mainly in patients with newly-formed stomas, with generally satisfactory effects. Stoma patients, due to a distorted body image and the loss of an essential body function, face difficulties in everyday life in terms of physical, psychological, and social aspects [107]. One of the most common psychosocial intervention described in this population is preoperative education, which appears to satisfactorily reduce both LOS and days to stoma proficiency $[108,109]$. Moreover, cognitive therapy and emotional support interventions such a relaxation training has proven to be feasible (even with follow-up telephone calls) and appear to reduce anxiety levels [110]. However, a major limitation is the small sample sizes of the studies [111].

Beneficial effects on quality of life with psychosocial interventions (mainly face-to-face approaches) [112] have been described [113]. Also, interventions focused on enriching communication with CRC patients have also been carried out. Ohlen et al. designed a person-centered information and communication intervention to study its beneficial effects on the patients' preparedness for surgery, discharge, and their subsequent recovery, but no conclusive results were obtained [114].

A favorable trend on the effectiveness of a positive emotion-based psychological therapy and a cognitive-behavioral therapy on the quality of life of CRC patients receiving adjuvant chemotherapy has been suggested, although findings were not conclusive [115].

Ellis et al. in a report of a longitudinal study of psychological adjustment in 326 patients with advanced cancer ( $43 \%$ corresponding to CRC), found how elderly patients (aged 70 years or more) were less frequently referred for specialized psychosocial care in comparison to younger subjects with the same degree of depressive symptoms [116]. Whether this finding is related to the illness being less destabilizing to an older person when compared to a younger counterpart or to a possible ageist bias for which caregivers may assume the benefits of these therapies is greater in younger subjects, remains unknown.

The shortage of evidence regarding the effect of psychotherapeutic interventions in cancer patients is striking considering how receiving a cancer diagnosis is a complex and stressful experience that constitutes a vital crisis that can present itself with very diverse emotional reactions (e.g., sadness, anger, confusion) [117]. Future studies should focus on studying some of the mostly inconclusive findings mentioned above, adhere to standards of quality research, and try to, not only increase the number of individuals per study, but also focus on certain subpopulations, such as the elderly.

\section{Conclusions}

CRC is a frequent disease among the elderly. Although fast-track circuits such as the ERAS program include the assessment of relevant problems for the elderly CRC patient (e.g., malnutrition), other aspects that could influence therapeutic approaches are normally left out, such as functionality, frailty, cognitive impairment, depression/anxiety or social support. The adequate evaluation of these conditions could lead to its control or improvement, and therefore a change in the patient's prognosis.

CGA has proven to be a useful tool for the identification and assessment of these conditions. It allows the multidisciplinary team (conformed by surgeons, anesthesiologists, nutritionists, pharmacologists, physical therapists, nurses, etc.) to design a thorough care plan that comprises both the oncologic treatment (surgery and/or adjuvant therapy) and the approach of geriatric syndromes through a multicomponent program. A program of these characteristics would be individualized, adjusted to the patient's situation and 
preferences, and could include nutritional, psychotherapeutic, pharmacologic or exercise interventions, among others. Possible outcomes to be assessed would include not only length of stay, in-hospital mortality, or post-operative complications, but also improvement on the physical, functional, cognitive and mental health situation, quality of life and readmissions in both the medium and long term post-operative period.

The scarcity of randomized controlled trials that evaluate the benefits of preoperative geriatric assessments or the use of multicomponent interventions, methodological variability among studies already published and the use of standard outcomes mostly centered on surgical aspects, could be some of the reasons why the evidence regarding the benefits of these programs remains unclear. In the authors' opinion, CGA should be the first step towards the creation of a multidisciplinary network which would give the patient access to a personalized treatment plan conformed by integral interventions. Although the evaluation of multicomponent programs of these characteristics is difficult, research on this matter seems necessary, as the complexity of elderly patients needs to be confronted not in just one field separately (be it the surgical, clinical, physical, or psychological), but in all of them together.

Author Contributions: Conceptualization: N.M.G.-S., J.M.-C., M.T.V.-A., J.A.S.-R., Search: N.M.G.-S., J.M.-C., M.L.C.A., L.M.J.-G., S.M.G., A.M.-V.; Writing-original draft preparation, N.M.G.-S., J.M.-C., M.L.C.A., S.M.G., P.A.-M., A.M.-V.; writing-review and editing, N.M.G.-S., J.M.-C., L.M.J.-G., J.A.S.R., M.T.V.-A., supervision, M.T.V.-A., J.A.S.-R.; funding acquisition, J.A.S.-R. All authors have read and agreed to the published version of the manuscript.

Funding: This study was supported by the Biomedical Research Networking Center on Frailty and Healthy Aging (CIBERFES, Spain); and FEDER funds from the European Union. The work of Jennifer Mayordomo-Cava is supported by a contract granted by Biomedical Research Networking Center on Frailty and Healthy Aging (CIBERFES, Spain).

Institutional Review Board Statement: Not applicable.

Informed Consent Statement: Not applicable.

Conflicts of Interest: The authors declare no conflict of interest.

\section{References}

1. Howlader, N.; Noone, A.; Krapcho, M.; Garshell, J.; Miller, D.; Altekruse, S.; Kosary, C.; Yu, M.; Ruhl, J.; Tatalovich, Z.; et al. SEER Cancer Statistics Review, 1975-2018; National Cancer Institute: Bethesda, MD, USA, 2020. Available online: https: / / seer.cancer.gov/csr/1975_2017/ (accessed on 30 January 2021).

2. Arnold, M.; Sierra, M.S.; Laversanne, M.; Soerjomataram, I.; Jemal, A.; Bray, F. Global patterns and trends in colorectal cancer incidence and mortality. Gut 2017, 66, 683-691. [CrossRef] [PubMed]

3. Ouakrim, D.A.; Pizot, C.; Boniol, M.; Malvezzi, M.; Boniol, M.; Negri, E.; Bota, M.; Jenkins, M.A.; Bleiberg, H.; Autier, P.J.B. Trends in colorectal cancer mortality in Europe: Retrospective analysis of the WHO mortality database. BMJ 2015, 351:h4970. [CrossRef] [PubMed]

4. Bray, F.; Ferlay, J.; Soerjomataram, I.; Siegel, R.L.; Torre, L.A.; Jemal, A. Global cancer statistics 2018: GLOBOCAN estimates of incidence and mortality worldwide for 36 cancers in 185 countries. CA Cancer J. Clin. 2018, 68, 394-424. [CrossRef] [PubMed]

5. Dekker, E.; Tanis, P.J.; Vleugels, J.L.A.; Kasi, P.M.; Wallace, M.B. Colorectal cancer. Lancet 2019, 394, 1467-1480. [CrossRef]

6. Bosman, F.T.; Carneiro, F.; Hruban, R.H.; Theise, N.D. WHO Classification of Tumours of the Digestive System, 4th ed.; World Health Organization, International Agency for Research on Cancer: Geneva, Switzerland, 2010.

7. Henrikson, N.B.; Webber, E.M.; Goddard, K.A.; Scrol, A.; Piper, M.; Williams, M.S.; Zallen, D.T.; Calonge, N.; Ganiats, T.G.; Janssens, A.C.; et al. Family history and the natural history of colorectal cancer: Systematic review. Genet. Med. Off. J. Am. Coll. Med Genet. 2015, 17, 702-712. [CrossRef]

8. Siegel, R.L.; Miller, K.D.; Goding Sauer, A.; Fedewa, S.A.; Butterly, L.F.; Anderson, J.C.; Cercek, A.; Smith, R.A.; Jemal, A. Colorectal cancer statistics, 2020. CA Cancer J. Clin. 2020, 70, 145-164. [CrossRef]

9. Wolf, A.M.D.; Fontham, E.T.H.; Church, T.R.; Flowers, C.R.; Guerra, C.E.; LaMonte, S.J.; Etzioni, R.; McKenna, M.T.; Oeffinger, K.C.; Shih, Y.T.; et al. Colorectal cancer screening for average-risk adults: 2018 guideline update from the American Cancer Society. CA Cancer J. Clin. 2018, 68, 250-281. [CrossRef]

10. Labianca, R.; Nordlinger, B.; Beretta, G.D.; Mosconi, S.; Mandala, M.; Cervantes, A.; Arnold, D.; Group, E.G.W. Early colon cancer: ESMO Clinical Practice Guidelines for diagnosis, treatment and follow-up. Ann. Oncol. 2013, 24 (Suppl. 6), vi64-vi72. [CrossRef] 
11. Jafari, M.D.; Jafari, F.; Halabi, W.J.; Nguyen, V.Q.; Pigazzi, A.; Carmichael, J.C.; Mills, S.D.; Stamos, M.J. Colorectal Cancer Resections in the Aging US Population: A Trend Toward Decreasing Rates and Improved Outcomes. JAMA Surg. 2014, 149, 557-564. [CrossRef]

12. Papamichael, D.; Audisio, R.A.; Glimelius, B.; de Gramont, A.; Glynne-Jones, R.; Haller, D.; Kohne, C.H.; Rostoft, S.; Lemmens, V.; Mitry, E.; et al. Treatment of colorectal cancer in older patients: International Society of Geriatric Oncology (SIOG) consensus recommendations 2013. Ann. Oncol. 2013, 26, 463-476. [CrossRef]

13. Simon, K. Colorectal cancer development and advances in screening. Clin. Interv. Aging 2016, 11, 967-976. [CrossRef]

14. Moreno, C.C.; Mittal, P.K.; Sullivan, P.S.; Rutherford, R.; Staley, C.A.; Cardona, K.; Hawk, N.N.; Dixon, W.T.; Kitajima, H.D.; Kang, J.; et al. Colorectal Cancer Initial Diagnosis: Screening Colonoscopy, Diagnostic Colonoscopy, or Emergent Surgery, and Tumor Stage and Size at Initial Presentation. Clin. Colorectal Cancer 2016, 15, 67-73. [CrossRef]

15. Force, U.P.S.T. Screening for Colorectal Cancer: US Preventive Services Task Force Recommendation Statement. JAMA 2016, 315, 2564-2575. [CrossRef]

16. Rex, D.K.; Boland, C.R.; Dominitz, J.A.; Giardiello, F.M.; Johnson, D.A.; Kaltenbach, T.; Levin, T.R.; Lieberman, D.; Robertson, D.J. Colorectal Cancer Screening: Recommendations for Physicians and Patients from the U.S. Multi-Society Task Force on Colorectal Cancer. Am. J. Gastroenterol. 2017, 112, 1016-1030. [CrossRef]

17. van Hees, F.; Habbema, J.D.; Meester, R.G.; Lansdorp-Vogelaar, I.; van Ballegooijen, M.; Zauber, A.G. Should colorectal cancer screening be considered in elderly persons without previous screening? A cost-effectiveness analysis. Ann. Intern. Med. 2014, 160, 750-759. [CrossRef]

18. van Leeuwen, B.L.; Pahlman, L.; Gunnarsson, U.; Sjovall, A.; Martling, A. The effect of age and gender on outcome after treatment for colon carcinoma. A population-based study in the Uppsala and Stockholm region. Crit. Rev. Oncol. Hematol. 2008, 67, 229-236. [CrossRef] [PubMed]

19. Colorectal Cancer Collaborative Group. Surgery for colorectal cancer in elderly patients: A systematic review. Lancet 2000, 356, 968-974. [CrossRef]

20. Sell, N.M.; Qwaider, Y.Z.; Goldstone, R.N.; Stafford, C.E.; Cauley, C.E.; Francone, T.D.; Ricciardi, R.; Bordeianou, L.G.; Berger, D.L.; Kunitake, H. Octogenarians present with a less aggressive phenotype of colon adenocarcinoma. Surgery 2020, 168, 1138-1143. [CrossRef]

21. Serra-Rexach, J.A.; Jimenez, A.B.; Garcia-Alhambra, M.A.; Pla, R.; Vidan, M.; Rodriguez, P.; Ortiz, J.; Garcia-Alfonso, P.; Martin, M. Differences in the therapeutic approach to colorectal cancer in young and elderly patients. Oncologist 2012, 17, 1277-1285. [CrossRef]

22. Townsley, C.A.; Selby, R.; Siu, L.L. Systematic review of barriers to the recruitment of older patients with cancer onto clinical trials. J. Clin. Oncol. Off. J. Am. Soc. Clin. Oncol. 2005, 23, 3112-3124. [CrossRef]

23. Pallis, A.G.; Papamichael, D.; Audisio, R.; Peeters, M.; Folprecht, G.; Lacombe, D.; Van Cutsem, E. EORTC Elderly Task Force experts' opinion for the treatment of colon cancer in older patients. Cancer Treat. Rev. 2010, 36, 83-90. [CrossRef] [PubMed]

24. Abraham, N.S.; Young, J.M.; Solomon, M.J. Meta-analysis of short-term outcomes after laparoscopic resection for colorectal cancer. Br. J. Surg. 2004, 91, 1111-1124. [CrossRef] [PubMed]

25. Braga, M.; Vignali, A.; Gianotti, L.; Zuliani, W.; Radaelli, G.; Gruarin, P.; Dellabona, P.; Di Carlo, V. Laparoscopic versus open colorectal surgery: A randomized trial on short-term outcome. Ann. Surg. 2002, 236, 759-766. [CrossRef]

26. Lacy, A.M.; Garcia-Valdecasas, J.C.; Delgado, S.; Castells, A.; Taura, P.; Pique, J.M.; Visa, J. Laparoscopy-assisted colectomy versus open colectomy for treatment of non-metastatic colon cancer: A randomised trial. Lancet 2002, 359, 2224-2229. [CrossRef]

27. Fujii, S.; Tsukamoto, M.; Fukushima, Y.; Shimada, R.; Okamoto, K.; Tsuchiya, T.; Nozawa, K.; Matsuda, K.; Hashiguchi, Y. Systematic review of laparoscopic vs open surgery for colorectal cancer in elderly patients. World J. Gastrointest. Oncol. 2016, 8 , 573-582. [CrossRef]

28. Hinoi, T.; Kawaguchi, Y.; Hattori, M.; Okajima, M.; Ohdan, H.; Yamamoto, S.; Hasegawa, H.; Horie, H.; Murata, K.; Yamaguchi, S.; et al. Laparoscopic versus open surgery for colorectal cancer in elderly patients: A multicenter matched case-control study. Ann. Surg. Oncol. 2015, 22, 2040-2050. [CrossRef]

29. Kannan, U.; Reddy, V.S.; Mukerji, A.N.; Parithivel, V.S.; Shah, A.K.; Gilchrist, B.F.; Farkas, D.T. Laparoscopic vs open partial colectomy in elderly patients: Insights from the American College of Surgeons-National Surgical Quality Improvement Program database. World J. Gastroenterol. 2015, 21, 12843-12850. [CrossRef]

30. Bircan, H.Y.; Koc, B.; Ozcelik, U.; Adas, G.; Karahan, S.; Demirag, A. Are there any differences between age groups regarding colorectal surgery in elderly patients? BMC Surg. 2014, 14, 44. [CrossRef]

31. Grosso, G.; Biondi, A.; Marventano, S.; Mistretta, A.; Calabrese, G.; Basile, F. Major postoperative complications and survival for colon cancer elderly patients. BMC Surg. 2012, 12 (Suppl. 1), S20. [CrossRef]

32. Marusch, F.; Koch, A.; Schmidt, U.; Steinert, R.; Ueberrueck, T.; Bittner, R.; Berg, E.; Engemann, R.; Gellert, K.; Arbogast, R.; et al. The impact of the risk factor "age" on the early postoperative results of surgery for colorectal carcinoma and its significance for perioperative management. World J. Surg. 2005, 29, 1013-1021; discussion 1021-1012. [CrossRef]

33. Kunitake, H.; Zingmond, D.S.; Ryoo, J.; Ko, C.Y. Caring for octogenarian and nonagenarian patients with colorectal cancer: What should our standards and expectations be? Dis. Colon Rectum 2010, 53, 735-743. [CrossRef]

34. Engel, A.F.; Oomen, J.L.; Knol, D.L.; Cuesta, M.A. Operative mortality after colorectal resection in the Netherlands. Br. J. Surg. 2005, 92, 1526-1532. [CrossRef] 
35. Faiz, O.; Haji, A.; Bottle, A.; Clark, S.K.; Darzi, A.W.; Aylin, P. Elective colonic surgery for cancer in the elderly: An investigation into postoperative mortality in English NHS hospitals between 1996 and 2007. Colorectal Dis. Off. J. Assoc. Coloproctol. Great Br. Irel. 2011, 13, 779-785. [CrossRef]

36. Dekker, J.W.; Gooiker, G.A.; Bastiaannet, E.; van den Broek, C.B.; van der Geest, L.G.; van de Velde, C.J.; Tollenaar, R.A.; Liefers, G.J.; Steering Committee of the 'Quality Information System Colorectal Cancer' Project. Cause of death the first year after curative colorectal cancer surgery; a prolonged impact of the surgery in elderly colorectal cancer patients. Eur. J. Surg. Oncol. J. Eur. Soc. Surg. Oncol. Br. Assoc. Surg. Oncol. 2014, 40, 1481-1487. [CrossRef]

37. Dekker, J.W.; van den Broek, C.B.; Bastiaannet, E.; van de Geest, L.G.; Tollenaar, R.A.; Liefers, G.J. Importance of the first postoperative year in the prognosis of elderly colorectal cancer patients. Ann. Surg. Oncol. 2011, 18, 1533-1539. [CrossRef]

38. Magnuson, A.; Sattar, S.; Nightingale, G.; Saracino, R.; Skonecki, E.; Trevino, K.M. A Practical Guide to Geriatric Syndromes in Older Adults With Cancer: A Focus on Falls, Cognition, Polypharmacy, and Depression. Am. Soc. Clin. Oncol. Educ. Book. Am. Soc. Clin. Oncology. Annu. Meet. 2019, 39, e96-e109. [CrossRef]

39. Reuben, D.B.; Rubenstein, L.V.; Hirsch, S.H.; Hays, R.D. Value of functional status as a predictor of mortality: Results of a prospective study. Am. J. Med. 1992, 93, 663-669. [CrossRef]

40. Wedding, U.; Rohrig, B.; Klippstein, A.; Pientka, L.; Hoffken, K. Age, severe comorbidity and functional impairment independently contribute to poor survival in cancer patients. J. Cancer Res. Clin. Oncol. 2007, 133, 945-950. [CrossRef]

41. Hamaker, M.E.; Prins, M.C.; Schiphorst, A.H.; van Tuyl, S.A.; Pronk, A.; van den Bos, F. Long-term changes in physical capacity after colorectal cancer treatment. J. Geriatr. Oncol. 2015, 6, 153-164. [CrossRef]

42. Ronning, B.; Wyller, T.B.; Jordhoy, M.S.; Nesbakken, A.; Bakka, A.; Seljeflot, I.; Kristjansson, S.R. Frailty indicators and functional status in older patients after colorectal cancer surgery. J. Geriatr. Oncol. 2014, 5, 26-32. [CrossRef] [PubMed]

43. Clegg, A.; Young, J.; Iliffe, S.; Rikkert, M.O.; Rockwood, K. Frailty in elderly people. Lancet 2013, 381, 752-762. [CrossRef]

44. Hoogendijk, E.O.; Afilalo, J.; Ensrud, K.E.; Kowal, P.; Onder, G.; Fried, L.P. Frailty: Implications for clinical practice and public health. Lancet 2019, 394, 1365-1375. [CrossRef]

45. Fried, L.P.; Tangen, C.M.; Walston, J.; Newman, A.B.; Hirsch, C.; Gottdiener, J.; Seeman, T.; Tracy, R.; Kop, W.J.; Burke, G.; et al. Frailty in older adults: Evidence for a phenotype. J. gerontology. Ser. A Biol. Sci. Med Sci. 2001, 56, M146-M156. [CrossRef] [PubMed]

46. Rockwood, K.; Song, X.; MacKnight, C.; Bergman, H.; Hogan, D.B.; McDowell, I.; Mitnitski, A. A global clinical measure of fitness and frailty in elderly people. CMAJ Can. Med Assoc. J. 2005, 173, 489-495. [CrossRef]

47. Collard, R.M.; Boter, H.; Schoevers, R.A.; Oude Voshaar, R.C. Prevalence of frailty in community-dwelling older persons: A systematic review. J. Am. Geriatr. Soc. 2012, 60, 1487-1492. [CrossRef]

48. Mohile, S.G.; Dale, W.; Somerfield, M.R.; Schonberg, M.A.; Boyd, C.M.; Burhenn, P.S.; Canin, B.; Cohen, H.J.; Holmes, H.M.; Hopkins, J.O.; et al. Practical Assessment and Management of Vulnerabilities in Older Patients Receiving Chemotherapy: ASCO Guideline for Geriatric Oncology. J. Clin. Oncol. Off. J. Am. Soc. Clin. Oncol. 2018, 36, 2326-2347. [CrossRef]

49. Morley, J.E.; Vellas, B.; van Kan, G.A.; Anker, S.D.; Bauer, J.M.; Bernabei, R.; Cesari, M.; Chumlea, W.C.; Doehner, W.; Evans, J.; et al. Frailty consensus: A call to action. J. Am. Med Dir. Assoc. 2013, 14, 392-397. [CrossRef]

50. Extermann, M.; Aapro, M.; Bernabei, R.; Cohen, H.J.; Droz, J.P.; Lichtman, S.; Mor, V.; Monfardini, S.; Repetto, L.; Sorbye, L.; et al. Use of comprehensive geriatric assessment in older cancer patients: Recommendations from the task force on CGA of the International Society of Geriatric Oncology (SIOG). Crit. Rev. Oncol. Hematol. 2005, 55, 241-252. [CrossRef]

51. Balducci, L.; Extermann, M. Management of cancer in the older person: A practical approach. Oncologist 2000, 5, 224-237. [CrossRef]

52. Saliba, D.; Elliott, M.; Rubenstein, L.Z.; Solomon, D.H.; Young, R.T.; Kamberg, C.J.; Roth, C.; MacLean, C.H.; Shekelle, P.G.; Sloss, E.M.; et al. The Vulnerable Elders Survey: A tool for identifying vulnerable older people in the community. J. Am. Geriatr. Soc. 2001, 49, 1691-1699. [CrossRef]

53. Bellera, C.A.; Rainfray, M.; Mathoulin-Pelissier, S.; Mertens, C.; Delva, F.; Fonck, M.; Soubeyran, P.L. Screening older cancer patients: First evaluation of the G-8 geriatric screening tool. Ann. Oncol. 2012, 23, 2166-2172. [CrossRef]

54. Fagard, K.; Leonard, S.; Deschodt, M.; Devriendt, E.; Wolthuis, A.; Prenen, H.; Flamaing, J.; Milisen, K.; Wildiers, H.; Kenis, C. The impact of frailty on postoperative outcomes in individuals aged 65 and over undergoing elective surgery for colorectal cancer: A systematic review. J. Geriatr. Oncol. 2016, 7, 479-491. [CrossRef]

55. Sáez-López, P.; Filipovich Vegas, E.; Martinez Peromingo, J.; Jimenez Mola, S. Colorectal cancer in the elderly. Surgical treatment, chemotherapy, and contribution from geriatrics. Rev. Esp. De Geriatr. Y Gerontol. 2017, 52, 261-270. (In Spanish) [CrossRef]

56. Robinson, T.N.; Walston, J.D.; Brummel, N.E.; Deiner, S.; Brown, C.H., IV; Kennedy, M.; Hurria, A. Frailty for Surgeons: Review of a National Institute on Aging Conference on Frailty for Specialists. J. Am. Coll. Surg. 2015, 221, 1083-1092. [CrossRef]

57. Gupta, S.K.; Lamont, E.B. Patterns of presentation, diagnosis, and treatment in older patients with colon cancer and comorbid dementia. J. Am. Geriatr. Soc. 2004, 52, 1681-1687. [CrossRef]

58. Derogatis, L.R.; Morrow, G.R.; Fetting, J.; Penman, D.; Piasetsky, S.; Schmale, A.M.; Henrichs, M.; Carnicke, C.L., Jr. The prevalence of psychiatric disorders among cancer patients. JAMA 1983, 249, 751-757. [CrossRef]

59. Massie, M.J. Prevalence of depression in patients with cancer. J. Natl. Cancer Inst. Monogr. 2004, 2004, 57-71. [CrossRef]

60. Peng, Y.N.; Huang, M.L.; Kao, C.H. Prevalence of Depression and Anxiety in Colorectal Cancer Patients: A Literature Review. Int. J. Environ. Res. Public Health 2019, 16. [CrossRef] 
61. Lloyd, S.; Baraghoshi, D.; Tao, R.; Garrido-Laguna, I.; Gilcrease, G.W., 3rd; Whisenant, J.; Weis, J.R.; Scaife, C.; Pickron, T.B.; Huang, L.C.; et al. Mental Health Disorders are More Common in Colorectal Cancer Survivors and Associated With Decreased Overall Survival. Am. J. Clin. Oncol. 2019, 42, 355-362. [CrossRef]

62. Mols, F.; Schoormans, D.; de Hingh, I.; Oerlemans, S.; Husson, O. Symptoms of anxiety and depression among colorectal cancer survivors from the population-based, longitudinal PROFILES Registry: Prevalence, predictors, and impact on quality of life. Cancer 2018, 124, 2621-2628. [CrossRef]

63. Zhang, A.Y.; Cooper, G.S. Recognition of Depression and Anxiety among Elderly Colorectal Cancer Patients. Nurs. Res. Pract. 2010, 2010, 693961. [CrossRef] [PubMed]

64. Arends, J.; Bachmann, P.; Baracos, V.; Barthelemy, N.; Bertz, H.; Bozzetti, F.; Fearon, K.; Hutterer, E.; Isenring, E.; Kaasa, S.; et al. ESPEN guidelines on nutrition in cancer patients. Clin. Nutr. 2017, 36, 11-48. [CrossRef] [PubMed]

65. Arends, J.; Baracos, V.; Bertz, H.; Bozzetti, F.; Calder, P.C.; Deutz, N.E.P.; Erickson, N.; Laviano, A.; Lisanti, M.P.; Lobo, D.N.; et al. ESPEN expert group recommendations for action against cancer-related malnutrition. Clin. Nutr. 2017, 36, 1187-1196. [CrossRef] [PubMed]

66. Zhang, X.; Edwards, B.J. Malnutrition in Older Adults with Cancer. Curr. Oncol. Rep. 2019, 21, 80. [CrossRef]

67. Kenis, C.; Bron, D.; Libert, Y.; Decoster, L.; Van Puyvelde, K.; Scalliet, P.; Cornette, P.; Pepersack, T.; Luce, S.; Langenaeken, C.; et al. Relevance of a systematic geriatric screening and assessment in older patients with cancer: Results of a prospective multicentric study. Ann. Oncol. 2013, 24, 1306-1312. [CrossRef]

68. Haviland, J.; Sodergren, S.; Calman, L.; Corner, J.; Din, A.; Fenlon, D.; Grimmett, C.; Richardson, A.; Smith, P.W.; Winter, J.; et al. Social support following diagnosis and treatment for colorectal cancer and associations with health-related quality of life: Results from the UK ColoREctal Wellbeing (CREW) cohort study. Psycho-Oncology 2017, 26, 2276-2284. [CrossRef]

69. Kristjansson, S.R.; Nesbakken, A.; Jordhøy, M.S.; Skovlund, E.; Audisio, R.A.; Johannessen, H.O.; Bakka, A.; Wyller, T.B Comprehensive geriatric assessment can predict complications in elderly patients after elective surgery for colorectal cancer: A prospective observational cohort study. Crit. Rev. Oncol. Hematol. 2010, 76, 208-217. [CrossRef]

70. Ommundsen, N.; Wyller, T.B.; Nesbakken, A.; Bakka, A.O.; Jordhoy, M.S.; Skovlund, E.; Rostoft, S. Preoperative geriatric assessment and tailored interventions in frail older patients with colorectal cancer: A randomized controlled trial. Colorectal Dis. Off. J. Assoc. Coloproctol. Great Br. Irel. 2018, 20, 16-25. [CrossRef]

71. Reisinger, K.W.; van Vugt, J.L.; Tegels, J.J.; Snijders, C.; Hulsewé, K.W.; Hoofwijk, A.G.; Stoot, J.H.; Von Meyenfeldt, M.F.; Beets, G.L.; Derikx, J.P.; et al. Functional compromise reflected by sarcopenia, frailty, and nutritional depletion predicts adverse postoperative outcome after colorectal cancer surgery. Ann. Surg. 2015, 261, 345-352. [CrossRef]

72. Tan, K.Y.; Kawamura, Y.J.; Tokomitsu, A.; Tang, T. Assessment for frailty is useful for predicting morbidity in elderly patients undergoing colorectal cancer resection whose comorbidities are already optimized. Am. J. Surg. 2012, 204, 139-143. [CrossRef]

73. Kehlet, H. Fast-track colorectal surgery. Lancet 2008, 371, 791-793. [CrossRef]

74. Vlug, M.S.; Wind, J.; Hollmann, M.W.; Ubbink, D.T.; Cense, H.A.; Engel, A.F.; Gerhards, M.F.; van Wagensveld, B.A.; van der Zaag, E.S.; van Geloven, A.A.; et al. Laparoscopy in combination with fast track multimodal management is the best perioperative strategy in patients undergoing colonic surgery: A randomized clinical trial (LAFA-study). Ann. Surg. 2011, 254, 868-875. [CrossRef]

75. Varadhan, K.K.; Neal, K.R.; Dejong, C.H.; Fearon, K.C.; Ljungqvist, O.; Lobo, D.N. The enhanced recovery after surgery (ERAS) pathway for patients undergoing major elective open colorectal surgery: A meta-analysis of randomized controlled trials. Clin. Nutr. 2010, 29, 434-440. [CrossRef]

76. Gonzalez-Ayora, S.; Pastor, C.; Guadalajara, H.; Ramirez, J.M.; Royo, P.; Redondo, E.; Arroyo, A.; Moya, P.; Garcia-Olmo, D. Enhanced recovery care after colorectal surgery in elderly patients. Compliance and outcomes of a multicenter study from the Spanish working group on ERAS. Int. J. Colorectal Dis. 2016, 31, 1625-1631. [CrossRef]

77. Rubenstein, L.Z.; Stuck, A.E.; Siu, A.L.; Wieland, D. Impacts of geriatric evaluation and management programs on defined outcomes: Overview of the evidence. J. Am. Geriatr. Soc. 1991, 39, 8S-16S. [CrossRef]

78. Wildiers, H.; Heeren, P.; Puts, M.; Topinkova, E.; Janssen-Heijnen, M.L.; Extermann, M.; Falandry, C.; Artz, A.; Brain, E.; Colloca, G.; et al. International Society of Geriatric Oncology consensus on geriatric assessment in older patients with cancer. J. Clin. Oncol. Off. J. Am. Soc. Clin. Oncol. 2014, 32, 2595-2603. [CrossRef]

79. Soto-Perez-de-Celis, E.; Aapro, M.; Muss, H. ASCO 2020: The Geriatric Assessment Comes of Age. Oncologist 2020, 25, 909-912. [CrossRef]

80. Jones, T.S.; Jones, E.L.; Richardson, V.; Finley, J.B.; Franklin, J.L.; Gore, D.L.; Horney, C.P.; Kovar, A.; Morin, T.L.; Robinson, T.N. Preliminary data demonstrate the Geriatric Surgery Verification program reduces postoperative length of stay. J. Am. Geriatr. Soc. 2021. [CrossRef]

81. Shahrokni, A.; Tin, A.L.; Sarraf, S.; Alexander, K.; Sun, S.; Kim, S.J.; McMillan, S.; Yulico, H.; Amirnia, F.; Downey, R.J.; et al. Association of Geriatric Comanagement and 90-Day Postoperative Mortality Among Patients Aged 75 Years and Older With Cancer. JAMA Netw. Open 2020, 3, e209265. [CrossRef]

82. Ghignone, F.; van Leeuwen, B.L.; Montroni, I.; Huisman, M.G.; Somasundar, P.; Cheung, K.L.; Audisio, R.A.; Ugolini, G.; International Society of Geriatric Oncology Surgical Task Force. The assessment and management of older cancer patients: A SIOG surgical task force survey on surgeons' attitudes. Eur. J. Surg. Oncol. J. Eur. Soc. Surg. Oncol. Br. Assoc. Surg. Oncol. 2016, 42, 297-302. [CrossRef] 
83. Lee, D.Y.; Kwak, J.M. Comprehensive Approach for Older Cancer Patients: New Challenge in an Aging Society. Ann. Coloproctol. 2020, 36, 289-290. [CrossRef] [PubMed]

84. Shipway, D.; Koizia, L.; Winterkorn, N.; Fertleman, M.; Ziprin, P.; Moorthy, K. Embedded geriatric surgical liaison is associated with reduced inpatient length of stay in older patients admitted for gastrointestinal surgery. Future Healthc. J. 2018, 5, $108-116$. [CrossRef] [PubMed]

85. Ramírez-Martín, R.; JA, G.M.; JL, M.M.; González-Montalvo, J.I. The efficiency of «Cross-speciality Geriatrics» in the comanagement of patients older than 80 years admitted to the General Surgery Service. Economic Results. Rev. Esp. Geriatr. Gerontol. 2021, 56, 87-90. [CrossRef] [PubMed]

86. Tarazona-Santabalbina, F.J.; Llabata-Broseta, J.; Belenguer-Varea, A.; Alvarez-Martinez, D.; Cuesta-Peredo, D.; Avellana-Zaragoza, J.A. A daily multidisciplinary assessment of older adults undergoing elective colorectal cancer surgery is associated with reduced delirium and geriatric syndromes. J. Geriatr. Oncol. 2019, 10, 298-303. [CrossRef]

87. Indrakusuma, R.; Dunker, M.S.; Peetoom, J.J.; Schreurs, W.H. Evaluation of preoperative geriatric assessment of elderly patients with colorectal carcinoma. A retrospective study. Eur. J. Surg. Oncol. J. Eur. Soc. Surg. Oncol. Br. Assoc. Surg. Oncol. 2015, 41, 21-27. [CrossRef]

88. Patel, A.V.; Friedenreich, C.M.; Moore, S.C.; Hayes, S.C.; Silver, J.K.; Campbell, K.L.; Winters-Stone, K.; Gerber, L.H.; George, S.M.; Fulton, J.E.; et al. American College of Sports Medicine Roundtable Report on Physical Activity, Sedentary Behavior, and Cancer Prevention and Control. Med. Sci. Sports Exerc. 2019, 51, 2391-2402. [CrossRef]

89. Schmid, D.; Leitzmann, M.F. Association between physical activity and mortality among breast cancer and colorectal cancer survivors: A systematic review and meta-analysis. Ann. Oncol. 2014, 25, 1293-1311. [CrossRef]

90. Schmitz, K.H.; Campbell, A.M.; Stuiver, M.M.; Pinto, B.M.; Schwartz, A.L.; Morris, G.S.; Ligibel, J.A.; Cheville, A.; Galvão, D.A.; Alfano, C.M. Exercise is medicine in oncology: Engaging clinicians to help patients move through cancer. CA Cancer J. Clin. 2019, 69, 468-484. [CrossRef]

91. Schmitz, K.H.; Courneya, K.S.; Matthews, C.; Demark-Wahnefried, W.; Galvao, D.A.; Pinto, B.M.; Irwin, M.L.; Wolin, K.Y.; Segal, R.J.; Lucia, A.; et al. American College of Sports Medicine roundtable on exercise guidelines for cancer survivors. Med. Sci. Sports Exerc. 2010, 42, 1409-1426. [CrossRef]

92. Lynch, B.M.; van Roekel, E.H.; Vallance, J.K. Physical activity and quality of life after colorectal cancer: Overview of evidence and future directions. Expert Rev. Qual. Life Cancer Care 2016, 1, 9-23. [CrossRef]

93. McGettigan, M.; Cardwell, C.R.; Cantwell, M.M.; Tully, M.A. Physical activity interventions for disease-related physical and mental health during and following treatment in people with non-advanced colorectal cancer. Cochrane Database Syst. Rev. 2020, 5, CD012864. [CrossRef]

94. Pollan, M.; Casla-Barrio, S.; Alfaro, J.; Esteban, C.; Segui-Palmer, M.A.; Lucia, A.; Martin, M. Exercise and cancer: A position statement from the Spanish Society of Medical Oncology. Clin. Transl. Oncol. Off. Publ. Fed. Span. Oncol. Soc. Natl. Cancer Inst. Mex. 2020, 22, 1710-1729. [CrossRef]

95. Berkel, A.E.M.; Bongers, B.C.; Kotte, H.; Weltevreden, P.; de Jongh, F.H.C.; Eijsvogel, M.M.M.; Wymenga, A.N.M.; BigirwamunguBargeman, M.; van der Palen, J.; van Det, M.J.; et al. Effects of Community-based Exercise Prehabilitation for Patients Scheduled for Colorectal Surgery With High Risk for Postoperative Complications: Results of a Randomized Clinical Trial. Ann. Surg. 2021. [CrossRef]

96. Carli, F.; Charlebois, P.; Stein, B.; Feldman, L.; Zavorsky, G.; Kim, D.J.; Scott, S.; Mayo, N.E. Randomized clinical trial of prehabilitation in colorectal surgery. Br. J. Surg. 2010, 97, 1187-1197. [CrossRef]

97. Dronkers, J.J.; Lamberts, H.; Reutelingsperger, I.M.; Naber, R.H.; Dronkers-Landman, C.M.; Veldman, A.; van Meeteren, N.L. Preoperative therapeutic programme for elderly patients scheduled for elective abdominal oncological surgery: A randomized controlled pilot study. Clin. Rehabil. 2010, 24, 614-622. [CrossRef]

98. Minnella, E.M.; Ferreira, V.; Awasthi, R.; Charlebois, P.; Stein, B.; Liberman, A.S.; Scheede-Bergdahl, C.; Morais, J.A.; Carli, F. Effect of two different pre-operative exercise training regimens before colorectal surgery on functional capacity: A randomised controlled trial. Eur. J. Anaesthesiol. 2020, 37, 969-978. [CrossRef]

99. Awasthi, R.; Minnella, E.M.; Ferreira, V.; Ramanakumar, A.V.; Scheede-Bergdahl, C.; Carli, F. Supervised exercise training with multimodal pre-habilitation leads to earlier functional recovery following colorectal cancer resection. Acta Anaesthesiol. Scand. 2019, 63, 461-467. [CrossRef]

100. Chia, C.L.; Mantoo, S.K.; Tan, K.Y. 'Start to finish trans-institutional transdisciplinary care': A novel approach improves colorectal surgical results in frail elderly patients. Colorectal Dis. Off. J. Assoc. Coloproctology Great Br. Irel. 2016, 18, O43-O50. [CrossRef]

101. Souwer, E.T.D.; Bastiaannet, E.; de Bruijn, S.; Breugom, A.J.; van den Bos, F.; Portielje, J.E.A.; Dekker, J.W.T. Comprehensive multidisciplinary care program for elderly colorectal cancer patients: "From prehabilitation to independence". Eur. J. Surg. Oncol. J. Eur. Soc. Surg. Oncol. Br. Assoc. Surg. Oncol. 2018, 44, 1894-1900. [CrossRef]

102. Bousquet-Dion, G.; Awasthi, R.; Loiselle, S.E.; Minnella, E.M.; Agnihotram, R.V.; Bergdahl, A.; Carli, F.; Scheede-Bergdahl, C. Evaluation of supervised multimodal prehabilitation programme in cancer patients undergoing colorectal resection: A randomized control trial. Acta Oncol. 2018, 57, 849-859. [CrossRef]

103. Carli, F.; Bousquet-Dion, G.; Awasthi, R.; Elsherbini, N.; Liberman, S.; Boutros, M.; Stein, B.; Charlebois, P.; Ghitulescu, G.; Morin, N.; et al. Effect of Multimodal Prehabilitation vs Postoperative Rehabilitation on 30-Day Postoperative Complications for Frail 
Patients Undergoing Resection of Colorectal Cancer: A Randomized Clinical Trial. JAMA Surg. 2020, 155, 233-242. [CrossRef] [PubMed]

104. Gillis, C.; Li, C.; Lee, L.; Awasthi, R.; Augustin, B.; Gamsa, A.; Liberman, A.S.; Stein, B.; Charlebois, P.; Feldman, L.S.; et al. Prehabilitation versus rehabilitation: A randomized control trial in patients undergoing colorectal resection for cancer. Anesthesiology 2014, 121, 937-947. [CrossRef] [PubMed]

105. Minnella, E.M.; Bousquet-Dion, G.; Awasthi, R.; Scheede-Bergdahl, C.; Carli, F. Multimodal prehabilitation improves functional capacity before and after colorectal surgery for cancer: A five-year research experience. Acta Oncol. 2017, 56, 295-300. [CrossRef] [PubMed]

106. Campbell, K.L.; Winters-Stone, K.M.; Wiskemann, J.; May, A.M.; Schwartz, A.L.; Courneya, K.S.; Zucker, D.S.; Matthews, C.E.; Ligibel, J.A.; Gerber, L.H.; et al. Exercise Guidelines for Cancer Survivors: Consensus Statement from International Multidisciplinary Roundtable. Med. Sci. Sports Exerc. 2019, 51, 2375-2390. [CrossRef] [PubMed]

107. Lim, S.H.; Chan, S.W.C.; Chow, A.; Zhu, L.; Lai, J.H.; He, H.G. Pilot trial of a STOMA psychosocial intervention programme for colorectal cancer patients with stomas. J. Adv. Nurs. 2019, 75, 1338-1346. [CrossRef] [PubMed]

108. Bryan, S.; Dukes, S. The Enhanced Recovery Programme for stoma patients: An audit. Br. J. Nurs. 2010, 19, 831-834. [CrossRef]

109. Chaudhri, S.; Brown, L.; Hassan, I.; Horgan, A.F. Preoperative intensive, community-based vs. traditional stoma education: A randomized, controlled trial. Dis. Colon Rectum 2005, 48, 504-509. [CrossRef]

110. Cheung, Y.L.; Molassiotis, A.; Chang, A.M. The effect of progressive muscle relaxation training on anxiety and quality of life after stoma surgery in colorectal cancer patients. Psycho-Oncology 2003, 12, 254-266. [CrossRef]

111. Danielsen, A.K.; Burcharth, J.; Rosenberg, J. Patient education has a positive effect in patients with a stoma: A systematic review. Colorectal Dis. Off. J. Assoc. Coloproctology Great Br. Irel. 2013, 15, e276-e283. [CrossRef]

112. Son, H.; Son, Y.J.; Kim, H.; Lee, Y. Effect of psychosocial interventions on the quality of life of patients with colorectal cancer: A systematic review and meta-analysis. Health Qual. Life Outcomes 2018, 16, 119. [CrossRef]

113. Hoon, L.S.; Chi Sally, C.W.; Hong-Gu, H. Effect of psychosocial interventions on outcomes of patients with colorectal cancer: A review of the literature. Eur. J. Oncol. Nurs. 2013, 17, 883-891. [CrossRef]

114. Ohlen, J.; Sawatzky, R.; Pettersson, M.; Sarenmalm, E.K.; Larsdotter, C.; Smith, F.; Wallengren, C.; Friberg, F.; Kodeda, K.; Carlsson, E. Preparedness for colorectal cancer surgery and recovery through a person-centred information and communication intervention-A quasi-experimental longitudinal design. PLoS ONE 2019, 14, e0225816. [CrossRef]

115. Louro, A.C.; Castro, J.F.; Blasco, T. Effects of a positive emotion-based adjuvant psychological therapy in colorectal cancer patients: A pilot study. Psicooncologia 2016, 13, 113-125.

116. Ellis, J.; Lin, J.; Walsh, A.; Lo, C.; Shepherd, F.A.; Moore, M.; Li, M.; Gagliese, L.; Zimmermann, C.; Rodin, G. Predictors of referral for specialized psychosocial oncology care in patients with metastatic cancer: The contributions of age, distress, and marital status. J. Clin. Oncol. Off. J. Am. Soc. Clin. Oncol. 2009, 27, 699-705. [CrossRef]

117. Newell, S.A.; Sanson-Fisher, R.W.; Savolainen, N.J. Systematic review of psychological therapies for cancer patients: Overview and recommendations for future research. J. Natl. Cancer Inst. 2002, 94, 558-584. [CrossRef] 